\title{
Aggregate and soil organic carbon dynamics in South Chilean Andisols
}

\author{
D. Huygens ${ }^{1}$, P. Boeckx ${ }^{1}$, O. Van Cleemput ${ }^{1}$, C. Oyarzún ${ }^{2}$, and R. Godoy ${ }^{3}$ \\ ${ }^{1}$ Laboratory of Applied Physical Chemistry - ISOFYS, Ghent University, Coupure 653, B-9000 Gent, Belgium \\ ${ }^{2}$ Institute of Geosciences, Universidad Austral de Chile, Casilla 567, Valdivia, Chile \\ ${ }^{3}$ Institute of Botany, Universidad Austral de Chile, Casilla 567, Valdivia, Chile
}

Received: 20 December 2004 - Published in Biogeosciences Discussions: 9 February 2005

Revised: 11 May 2005 - Accepted: 6 June 2005 - Published: 24 June 2005

\begin{abstract}
Extreme sensitivity of soil organic carbon (SOC) to climate and land use change warrants further research in different terrestrial ecosystems. The aim of this study was to investigate the link between aggregate and SOC dynamics in a chronosequence of three different land uses of a south Chilean Andisol: a second growth Nothofagus obliqua forest (SGFOR), a grassland (GRASS) and a $P i$ nus radiata plantation (PINUS). Total carbon content of the $0-10 \mathrm{~cm}$ soil layer was higher for GRASS $\left(6.7 \mathrm{~kg} \mathrm{C} \mathrm{m}^{-2}\right)$ than for PINUS $\left(4.3 \mathrm{~kg} \mathrm{C} \mathrm{m}^{-2}\right)$, while TC content of SGFOR $\left(5.8 \mathrm{~kg} \mathrm{C} \mathrm{m}^{-2}\right)$ was not significantly different from either one. High extractable oxalate and pyrophosphate $\mathrm{Al}$ concentrations (varying from $20.3-24.4 \mathrm{~g} \mathrm{~kg}^{-1}$, and $3.9-$ $11.1 \mathrm{~g} \mathrm{~kg}^{-1}$, respectively) were found in all sites. In this study, SOC and aggregate dynamics were studied using size and density fractionation experiments of the SOC, $\delta^{13} \mathrm{C}$ and total carbon analysis of the different SOC fractions, and C mineralization experiments. The results showed that electrostatic sorption between and among amorphous $\mathrm{Al}$ components and clay minerals is mainly responsible for the formation of metal-humus-clay complexes and the stabilization of soil aggregates. The process of ligand exchange between SOC and $\mathrm{Al}$ would be of minor importance resulting in the absence of aggregate hierarchy in this soil type. Whole soil C mineralization rate constants were highest for SGFOR and PINUS, followed by GRASS (respectively $0.495,0.266$ and $0.196 \mathrm{~g} \mathrm{CO}_{2}-\mathrm{C} \mathrm{m}^{-2} \mathrm{~d}^{-1}$ for the top soil layer). In contrast, incubation experiments of isolated macro organic matter fractions gave opposite results, showing that the recalcitrance of the SOC decreased in another order: PINUS $>$ SGFOR $>$ GRASS. We deduced that electrostatic sorption processes and physical protection of SOC in soil aggregates were the main processes determining SOC stabilization. As a result, high aggregate carbon concentra-
\end{abstract}

Correspondence to: D. Huygens

(dries.huygens@ugent.be) tions, varying from 148 till $48 \mathrm{~g} \mathrm{~kg}^{-1}$, were encountered for all land use sites. $\mathrm{Al}$ availability and electrostatic charges are dependent on $\mathrm{pH}$, resulting in an important influence of soil $\mathrm{pH}$ on aggregate stability. Recalcitrance of the SOC did not appear to largely affect SOC stabilization. Statistical correlations between extractable amorphous $\mathrm{Al}$ contents, aggregate stability and $\mathrm{C}$ mineralization rate constants were encountered, supporting this hypothesis. Land use changes affected SOC dynamics and aggregate stability by modifying soil $\mathrm{pH}$ (and thus electrostatic charges and available $\mathrm{Al}$ content), root SOC input and management practices (such as ploughing and accompanying drying of the soil).

\section{Introduction}

Andisols develop from volcanic ash and are characterized by a high soil organic matter (SOM) content, good physical properties, and a high potential anion- or cation exchange capacity (AEC and CEC) (Galindo and Bingham, 1977). Their clay fraction consists mainly of poorly crystalline allophane, imogolite, and oxides and oxyhydroxides of $\mathrm{Fe}$ and $\mathrm{Al}$ (Besoain, 1958). Allophane is a group of clay minerals made up of silica, aluminum, and water in a chemical combination (Parfitt, 1990). In southern Chile $\left(35^{\circ}-49^{\circ} \mathrm{S}\right)$, Andisols cover a large part of the surface area of the Central Valley and Andes mountain ranges (FAO-UNESCO, 1971).

Temperate native forests covered most of southern Chile for the last 3,000 years, remaining almost intact until the arrival of the Europeans, 450 years ago (Lara et al., 1999). Significant land use changes have taken place in this region (Lara et al., 1999). Today, only 56\% (or 10.3 million ha) of this original forest cover remains. Most affected are the Sclerophyllus and the Nothofagus forest types, with 3 and 30\% of the original forest cover remaining, respectively (Lara et al., 1999). On the other hand, grasslands and shrublands have doubled in area, from 2.5 to 5.5 million ha (Lara

(C) 2005 Author(s). This work is licensed under a Creative Commons License. 
et al., 1999). New land use types, such as urban areas (55000 ha), arable lands ( 2.8 million ha) and forestry plantations (2.1 million ha), now occupy a significant area as well.

General overviews of changes in soil organic carbon (SOC) stocks after land use conversions are given by Guo and Gifford (2002) and Paul et al. (2002). Guo and Gifford (2002) revised changes in SOC stocks as a result of land use conversion, using data from 74 publications. They indicated that SOC stocks increase after land use change from native forest to pasture ( $+8 \%$, based on 170 observations), but declined after pasture conversion to plantation $(-10 \%$, based on 83 observations). However, rainfall has a strong influence on changes in SOC stocks. It was concluded that in areas receiving 1500-2000 $\mathrm{mm}$ of rainfall per year a conversion from forest to pasture did not result in changes in SOC stock. A land use change from grassland to plantation resulted in a significant decrease in SOC stock with $-23 \%$. Paul et al. (2002) concluded that afforestation decreased soil stocks by $3.5 \%$ per year during the first five years of afforestation. Later on, a decreasing rate of decline or eventually a recovery of SOC would occur. De Koning et al. (2003) concluded more specific that in Al-rich soils, changes in SOC stocks follow a pattern according to land use history and accompanying changes in soil characteristics.

Soil organic matter has a very complex and heterogeneous composition and is generally mixed or associated with the mineral soil constituents to form soil aggregates (Del Galdo et al., 2003). SOC dynamics are mainly influenced by its recalcitrance and accessibility, and interactions between SOC and soil components (Sollins et al., 1996). Recalcitrance is the inherent molecular level resistance of a molecule to microbial and enzymatic breakdown. Accessibility is the extent to which the location of substrates controls access by microbes, fungi or enzymes. Interactions of organic substrates with organic or inorganic molecules may alter the degradation rate of the substrates (Swanston et al., 2002). Several studies have shown that in $\mathrm{Al}$ rich soils, such as Andisols, chemical stabilization is the determining process for carbon accrual (Zunino et al., 1982; Percival et al., 2000). However, the exact role of SOC and $\mathrm{Al}$ in the process of chemical stabilization, and which kind of interactions occurs between the different soil components is not yet fully understood.

The objective of this study was to evaluate the role of $\mathrm{Al}$ on SOC dynamics in Chilean Andisols and to investigate SOC stabilization by electrostatic Al-C binding, and occlusion within soil aggregates. Via a case study, we tried to assess the effect of changes in certain physical and chemical soil characteristics - which resulted from the land use conversions - on SOC, physical protection of SOC in aggregates, quality of SOC, and organo-mineral associations. A chronosequence of three different land uses was studied: a second growth Nothofagus obliqua forest (SGFOR), a grassland (GRASS), and a plantation of Pinus radiata (PINUS).

\section{Materials and methods}

\subsection{Site description and soil sampling}

Soil samples were taken in August 2002 near Paillaco, in the Central Valley of southern Chile $\left(40^{\circ} 07 \mathrm{~S}, 72^{\circ} 51 \mathrm{~W}\right)$. The mean annual precipitation varies from $1600-1800 \mathrm{~mm}$, while mean annual temperature is $10.8^{\circ} \mathrm{C}$. All soils were classified as trumao's or Andisols, Typic Dysandrepts (Tosso, 1985). They have typical variable electrical charge characteristics (i.e. $\mathrm{pH}$ dependent) as a result of their particular clay mineral and humus content (Radcliffe and Gillman, 1985; Nanzyo et al., 1993). A mixture of $1: 1$ and 2:1 clay minerals (e.g. halloysite, vermiculite, etc.) has been documented in Chilean Andisols as well as the generally observed poorly crystalline minerals (Besoain, 1958, 1969; Galindo and Bingham, 1977; Besoain et al., 2000).

The three sites are all located in close proximity $(100 \mathrm{~m}$ apart) and were originally all under the same forest vegetation dominated by Nothofagus obliqua. Nowadays, only the SGFOR site is still under this original vegetation. The land use of the GRASS and PINUS sites changed 50-100 years ago from second growth $N$. obliqua forest to grassland for agricultural livestock activity. Finally, 16 years ago, a Pinus radiata plantation was established on part of the GRASS site.

The second growth $N$. obliqua forest (SGFOR) has a mean tree height of $35 \mathrm{~m}$, a stand density of $757 \mathrm{ha}^{-1}$ and a canopy cover of $70 \%$ during the growing season. The average tree age is 120 years, while mean diameter at breast height equals $42.5 \mathrm{~cm}$. In this forest, the overstorey is dominated by $N$. obliqua (32 m) with a cover of $40 \%$. The understorey ( $25 \mathrm{~m})$ consists of Aextoxicon punctatum, Persea linque, Nothofagus obliqua, Eucriphia cordifolia, Laurelia sempervirens, Nothofagus dombeyi and Gevuina avellana with a cover of $70 \%$. The lower understorey $(10 \mathrm{~m})$ is dominated by Aextoxicon punctatum. In the shrub stratum $(<4 \mathrm{~m})$ Chusquea quila and Raphithamnus spinosus are dominant.

Since the establishment of the pasture, agricultural activities (cattle breeding) have taken place on the GRASS and PINUS sites with an animal density of $1.5-2$ cows ha ${ }^{-1}$. The grassland has a species composition consisting of Lolium perenne and Trifolium repens, and is ploughed and resown every two years. A mixture of various forms of acidifying fertilizers has been applied yearly on the GRASS site at high levels, though no data were available on the exact fertilizer type or application rate.

On the PINUS site, fertilization was stopped with the establishment of the plantation, 16 years ago. This $P$. radiata monoculture has a mean tree height of $15-18 \mathrm{~m}$, while stand density is around $1500 \mathrm{ha}^{-1}$.

Sampling was done after selection of representative plots in the three ecosystem sites (land use treatments). In each land use treatment, three sampling plots were selected based on pedological, forestry and ecological experience, and were located approximately $20 \mathrm{~m}$ apart from each other. Samples 


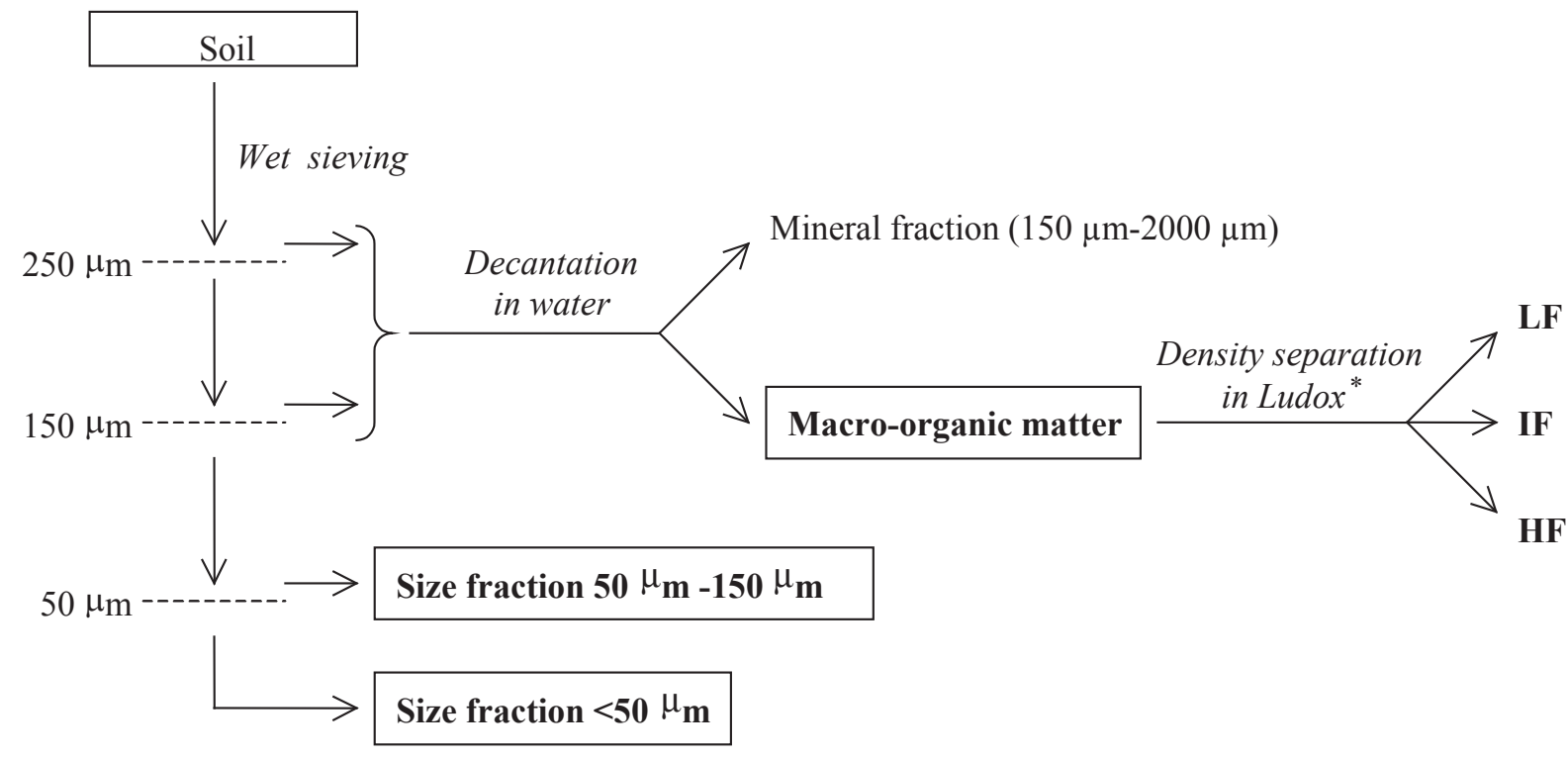

*Ludox : silica suspensions with different density

Fig. 1. Scheme of the density fractionation of SOC; $\mathrm{LF}=$ light density fraction (density $<1.13 \mathrm{Mg} \mathrm{m}^{-3}$ ), IF=intermediate density fraction $\left(1.13 \mathrm{Mg} \mathrm{m}^{-3}<\right.$ density $<1.37 \mathrm{Mg} \mathrm{m}^{-3}$ ), $\mathrm{HF}=$ heavy density fraction (density $>1.37 \mathrm{Mg} \mathrm{m}^{-3}$ ) (adapted from Accoe et al., 2002).

originating from a different sampling plot in the same land use treatment were considered as replicates, and were kept separate for later analysis. In each sampling plot, one soil sample has been taken at $0-10,10-20$ and $20-30 \mathrm{~cm}$ depth from a soil pit. Thus, in total 27 soil samples were taken. After transport to the laboratory, the recognizable plant material was removed. All soil samples were dried, homogenized and sieved $(2 \mathrm{~mm})$ for later analyses. Soil samples were dried in open air to a gravimetric water content of approximately $20 \%$. Volcanic-ash soils can granulate irreversibly when completely dried (Kubota, 1972), and this can affect the subsequent fractionation of SOC. We will refer to these partly dried samples using the term "air dried samples".

Bulk densities were determined by pushing steel cylinders with a known volume into the undisturbed soil (Klute, 1986). After transport to the laboratory, the cylinders were dried at $105^{\circ} \mathrm{C}$ during $24 \mathrm{~h}$, after which its weight was determined. Three replicates per land use treatment were performed. Soil texture was determined in the field according to a method described by Milford (1997).

\subsection{Size and density fractionation of SOC}

The size fractionation procedure was performed by separately wet sieving a soil sample of $100 \mathrm{~g}$ over three sieves ( $250 \mu \mathrm{m}, 150 \mu \mathrm{m}$ and $50 \mu \mathrm{m})$ with tap water. The suspension passing the bottom size was collected and left about $48 \mathrm{~h}$ at room temperature to settle. After settling, the clear solution was removed and the size fraction $<50 \mu \mathrm{m}$ was collected. Four size fractions $(2000-250 \mu \mathrm{m}, 250-150 \mu \mathrm{m}$, $150-50 \mu \mathrm{m}$ and $<50 \mu \mathrm{m}$ ) were obtained, dried at $40^{\circ} \mathrm{C}$ for $48 \mathrm{~h}$ and homogenized using a planetary ball mill (PM400, Retsch, Germany) for subsequent analysis.

To evaluate the soil aggregate stability or susceptibility of the aggregates against disruption processes, we used a modification of the procedure described by De Leenheer and De Boodt (1959). The size fractionation was performed at two different times, using the same procedure: (1) starting from "air dried" soil (slaking) and (2) after an 80 day laboratory incubation experiment (wet sieving of field moist soil) (see below). In the incubation experiment, the soil was exposed to several supplementary disruption processes such as rewetting and mixing of the soils. The distribution of the soil weight among the different size fractions was expressed using the weighted average diameter (WAD) and could thus be quantified as one single parameter for further statistical analyses. The difference in WAD between the two fractionation experiments can be related to the stability of the soil aggregates (De Leenheer and De Boodt, 1959). A smaller difference in WAD indicates a higher stability of the soil aggregates.

Density fractionation of the SOC was performed using the method of Meijboom et al. (1995) (Fig. 1). Air dried soil samples $(400 \mathrm{~g})$ were wet sieved over two sieves with tap water (top sieve mesh size $250 \mu \mathrm{m}$, bottom sieve mesh size $150 \mu \mathrm{m}$ ), until the passing water became clear in order to destroy aggregates $>150 \mu \mathrm{m}$. Only a water jet was applied as dispersive energy in order to destroy soil aggregates. Next, 
the two size fractions retained on the sieves were washed into a bucket and swirled with a jet of water to separate the organic matter $(\mathrm{OM})$ from the mineral fraction by decantation. Swirling and decanting were repeated until no more floating organic matter appeared. The obtained macro organic matter (MOM) from both size fractions (250-2000 and $150-250 \mu \mathrm{m})$ was recombined to be further separated into a light (LF, density $<1.13 \mathrm{Mg} \mathrm{m}^{-3}$ ), intermediate (IF, $1.13 \mathrm{Mg} \mathrm{m}^{-3}<$ density $<1.37 \mathrm{Mg} \mathrm{m}^{-3}$ ) and heavy (HF, density $>1.37 \mathrm{Mg} \mathrm{m}^{-3}$ ) fraction by subsequent submersion in two colloidal silica suspensions (Ludox, Dupont, USA) with a respective density of $1.13 \mathrm{Mg} \mathrm{m}^{-3}$ and $1.37 \mathrm{Mg} \mathrm{m}^{-3}$. The obtained density fractions were washed with distilled water and dried at $40^{\circ} \mathrm{C}$ for $48 \mathrm{~h}$.

The $\mathrm{C}$ concentrations increase with decreasing density of the fractions $(\mathrm{LF}>\mathrm{IF}>\mathrm{HF})$. The IF and HF show a higher association of the SOC of these heavier fractions with soil minerals (Hassink, 1995). The LF consists mainly of recognizable plant material in an early stage of decomposition and serves as readily decomposable substrate for the microbial biomass (Six et al., 1999; Solomon et al., 2000).

\subsection{C mineralization experiments}

The $\mathrm{C}$ mineralization experiments consisted out of two different experiments. In a first experiment, whole soil $\mathrm{C}$ mineralization was measured. In a second experiment, isolated macro organic matter fractions (LF and HF) were incubated to determine the specific $\mathrm{C}$ mineralization of these fractions.

Before starting the whole soil $\mathrm{C}$ mineralization experiment, the air dried soil was rewetted and pre-incubated during six days at a temperature of $15^{\circ} \mathrm{C}$. Air dried bulk samples were brought to a gravimetric water content of $46 \%$ for SGFOR and PINUS, respectively, and 32\% for GRASS, corresponding to a water-filled pore space of $25 \%$ at the bulk density in the field (using a bulk density for all the layers of $0.45 \mathrm{Mg} \mathrm{m}^{-3}$ for SGFOR and PINUS, and $0.60 \mathrm{Mg} \mathrm{m}^{-3}$ for GRASS (see Table 1) and a soil particle density of $2.65 \mathrm{Mg} \mathrm{m}^{-3}$ ). As such, a realistic microbial soil activity could be restored. An exact quantity of soil was put in PVC tubes $(4.6 \mathrm{~cm}$ diameter, $13 \mathrm{~cm}$ high) and compressed manually to the corresponding bulk density. The tubes were covered with parafilm, which permits sufficient gas exchange and aeration, but reduced moisture loss. During the entire experiment, the moisture content and temperature were kept constant. Carbon dioxide emission was measured on eight different time points (day 1, 3, 7, 11, 17, 35, 43 and 62). This was done by putting the PVC-tubes into glass jars, which were closed airtight. The headspace of the glass jars was sampled after $0,27,54$ and 81 minutes through a rubber septum. Before sampling, the $\mathrm{CO}_{2}$ concentration in the headspace was homogenized by repeatedly sucking and reinjecting the headspace. A gas sample of $1 \mathrm{~mL}$ was injected into a gas chromatograph (GC-14B, Shimadzu, Japan) (Porapack Q, mesh size 80/100 column specification, electron cap- ture detector (ECD)). The $\mathrm{CO}_{2}$ concentration was calculated via a linear calibration using a certified $\mathrm{CO}_{2}$ concentration ( $1 \% \mathrm{CO}_{2}$ in dry air, Air Liquide, France). Linear regression between the measuring points at $0,27,54$ and $81 \mathrm{~min}$ gave the $\mathrm{CO}_{2}$ mineralization flux.

The incubation of the isolated HF and LF was only performed for SOC originating from the $0-10 \mathrm{~cm}$ soil layer of each land use treatment, following the method described by Swanston et al. (2002). For LF, $2.00 \mathrm{~g}$ substrate was mixed with $18.00 \mathrm{~g}$ inert quartz sand (acid washed, $580-650 \mu \mathrm{m}$ diameter) in a glass flask. For HF, $5.00 \mathrm{~g}$ substrate was mixed with $15.00 \mathrm{~g}$ inert quartz sand. A microbial inoculum was added at the beginning of the incubation. A water extract from the mineral soil originating from the same soil layer was used as inoculum source. The inoculum was made by adding distilled water to a wet soil in a 1/1.5 ratio, followed by placing the mixture on a rotary shaker for $30 \mathrm{~min}$. After settling down, $4 \mathrm{~mL}$ of the supernatant was added to each flask and the substrate was pre-incubated for two days. During the entire experiment, the inoculated flasks were stored in an incubation room at a constant temperature of $15^{\circ} \mathrm{C}$. The $\mathrm{CO}_{2}$ concentration was measured through a septum in the cap of the flasks after $0,27,54$ and $81 \mathrm{~min}$ and on six different time points (day 1, 3, 7, 11, 17 and 35) with a gas chromatograph (GC-14B, Shimadzu, Japan), using the same method as described above.

\subsection{Physico-chemical analyses}

Measurement of ${ }^{13} \mathrm{C}$ and total $\mathrm{C}$ (TC) content in the different soils and SOC fractions was performed using an elemental analyser (ANCA-SL, PDZ-Europa, UK) coupled to an Isotope Ratio Mass Spectrometer (20-20, PDZ Europa, UK). The measured ${ }^{13} \mathrm{C} /{ }^{12} \mathrm{C}$ ratios are expressed as $\delta^{13} \mathrm{C}$ values $(\% o)$ vs. the international Vienna Pee Dee Belemnite (VPDB) standard:

$\delta^{13} \mathrm{C}=\frac{\mathrm{R}_{\text {sample }}-\mathrm{R}_{\text {standard }}}{\mathrm{R}_{\text {standard }}} \times 1000(\% o)$

$\mathrm{R}_{\text {sample and }} \mathrm{R}_{\text {standard }}$ refer to the ${ }^{13} \mathrm{C} /{ }^{12} \mathrm{C}$ ratio of the measured sample and the standard, respectively. The working standard was flour with a $\delta^{13} \mathrm{C}$ value of $-27.01 \pm 0.04 \%$ vs. VPDB and TC of $39.95 \pm 0.40 \%$ o (certified by Iso-Analytical, UK).

A modified procedure of the method described by Schwertmann (1964), using a mixture of ammonium oxalate $(0.2 \mathrm{M})$ and oxalic acid as extractant, was applied for the determination of the extractable aluminum oxalate $\left(\mathrm{Al}_{\mathrm{ox}}\right)$, and silicon oxalate $\left(\mathrm{Si}_{\mathrm{OX}}\right)$ content. In the absence of light, a soil:solution $(1: 10)$ mixture was placed on a rotary shaker for 2 hours. A pyrophosphate reagent $(0.1 \mathrm{M})$ was used in soil:solution ratio of 1:10 (shaking time $16 \mathrm{~h}$ ) for the determination of the pyrophosphate extractable $\mathrm{Al}$ content $\left(\mathrm{Al}_{\mathrm{py}}\right)$. All supernatants were centrifuged at $3000 \mathrm{rpm}$ for $10 \mathrm{~min}$, filtrated (folded filters, Schleicher \& Schüell, Germany) and 
Table 1. Chemical and physical properties of the second growth forest (SGFOR), grassland (GRASS) and plantation (PINUS) for the 0-10, 10-20 and 20-30 cm soil layer (Standard deviations between brackets, significant differences $(p<0.05)$ between land use treatments within one soil depth layer are indicated by different letters).

\begin{tabular}{|c|c|c|c|c|c|c|c|c|c|c|c|c|c|}
\hline \multirow{2}{*}{$\begin{array}{c}\text { Soil layer } \\
\mathrm{cm}\end{array}$} & \multirow[t]{2}{*}{ Land use class } & \multirow[t]{2}{*}{ Texture } & \multirow{2}{*}{$\mathrm{pH}_{\mathrm{H}_{2} \mathrm{O}}$} & \multirow{2}{*}{$\frac{\rho_{b}}{\mathrm{Mg} \mathrm{m}^{-3}}$} & \multirow{2}{*}{$\frac{\mathrm{Al}_{\mathrm{OX}}}{-}$} & \multirow{2}{*}{$\begin{array}{c}\mathrm{Al}_{\mathrm{py}} \\
\mathrm{g} \mathrm{kg}^{-1} \\
\end{array}$} & \multirow{2}{*}{$\begin{array}{c}\mathrm{Si}_{\mathrm{ox}} \\
-\end{array}$} & \multirow{2}{*}{$\begin{array}{c}\text { Allophane } \\
\%\end{array}$} & \multicolumn{2}{|c|}{$\mathrm{TC}$} & \multicolumn{2}{|c|}{$\mathrm{TN}$} & \multirow[t]{2}{*}{$\mathrm{C} / \mathrm{N}$} \\
\hline & & & & & & & & & $\mathrm{kgCm}^{-2}$ & $\mathrm{~g} \mathrm{~kg}^{-1}$ & $\mathrm{~kg} \mathrm{~N} \mathrm{~m}^{-2}$ & $\mathrm{~g} \mathrm{~kg}^{-1}$ & \\
\hline \multirow{3}{*}{$0-10$} & SGFOR & sandy loam & $\begin{array}{l}6.1^{a} \\
(0.1)\end{array}$ & $\begin{array}{c}0.42 \\
(0.06)\end{array}$ & $\begin{array}{c}20.3^{b} \\
(0.5)\end{array}$ & $\begin{array}{l}6.4^{b} \\
(0.9)\end{array}$ & $\begin{array}{c}9.6 \\
(0.4)\end{array}$ & $\begin{array}{l}6.00^{a} \\
(0.33)\end{array}$ & $\begin{array}{c}5.8^{a, b} \\
(0.5)\end{array}$ & $\begin{array}{c}139^{a} \\
(7)\end{array}$ & $\begin{array}{l}0.31^{b} \\
(0.05)\end{array}$ & $\begin{array}{l}7.4^{b} \\
(0.2)\end{array}$ & $\begin{array}{l}18.9 \\
(1.2)\end{array}$ \\
\hline & GRASS & sandy loam & $\begin{array}{l}5.7^{b} \\
(0.1)\end{array}$ & $\begin{array}{c}0.60 \\
(0.09)\end{array}$ & $\begin{array}{r}23.6^{a} \\
(0.5)\end{array}$ & $\begin{array}{c}11.1^{a} \\
(0.9)\end{array}$ & $\begin{array}{c}8.1 \\
(0.6)\end{array}$ & $\begin{array}{l}5.22^{b} \\
(0.28)\end{array}$ & $\begin{array}{l}6.7^{a} \\
(1.1)\end{array}$ & $\begin{array}{c}111^{b} \\
(1)\end{array}$ & $\begin{array}{l}0.53^{a} \\
(0.08)\end{array}$ & $\begin{array}{l}8.9^{a} \\
(0.1)\end{array}$ & $\begin{array}{l}12.5 \\
(4.5)\end{array}$ \\
\hline & PINUS & sandy loam & $\begin{array}{l}6.2^{a} \\
(0.0)\end{array}$ & $\begin{array}{c}0.45 \\
(0.07)\end{array}$ & $\begin{array}{r}22.9^{a} \\
(0.4)\end{array}$ & $\begin{array}{l}6.3^{b} \\
(0.8)\end{array}$ & $\begin{array}{c}9.1 \\
(0.2)\end{array}$ & $\begin{array}{l}6.46^{a} \\
(0.21)\end{array}$ & $\begin{array}{l}4.3^{b} \\
(0.9)\end{array}$ & $\begin{array}{l}94^{c} \\
(6)\end{array}$ & $\begin{array}{l}0.31^{b} \\
(0.06)\end{array}$ & $\begin{array}{l}6.8^{b} \\
(0.6)\end{array}$ & $\begin{array}{l}13.8 \\
(5.0)\end{array}$ \\
\hline \multirow{3}{*}{$10-20$} & SGFOR & sandy loam & $\begin{array}{l}6.3^{a} \\
(0.0)\end{array}$ & $\begin{array}{c}0.44 \\
(0.12)\end{array}$ & $\begin{array}{c}21.2^{b} \\
(0.6)\end{array}$ & $\begin{array}{l}5.4^{b} \\
(0.7)\end{array}$ & $\begin{array}{l}11.4 \\
(0.6)\end{array}$ & $\begin{array}{l}6.99^{a} \\
(0.12)\end{array}$ & $\begin{array}{l}4.0^{b} \\
(0.9)\end{array}$ & $\begin{array}{c}93^{b} \\
(6)\end{array}$ & $\begin{array}{l}0.23^{b} \\
(0.02)\end{array}$ & $\begin{array}{l}5.5^{b} \\
(1.2)\end{array}$ & $\begin{array}{l}16.9 \\
(0.6)\end{array}$ \\
\hline & GRASS & sandy loam & $\begin{array}{l}5.4^{b} \\
(0.1)\end{array}$ & $\begin{array}{c}0.46 \\
(0.10)\end{array}$ & $\begin{array}{c}24.1^{a} \\
(0.2)\end{array}$ & $\begin{array}{l}10.5^{a} \\
(1.0)\end{array}$ & $\begin{array}{c}8.5 \\
(0.3)\end{array}$ & $\begin{array}{l}5.57^{b} \\
(0.27)\end{array}$ & $\begin{array}{l}4.8^{b} \\
(1.0)\end{array}$ & $\begin{array}{c}105^{a} \\
(5)\end{array}$ & $\begin{array}{l}0.37^{a} \\
(0.08)\end{array}$ & $\begin{array}{l}8.1^{a} \\
(0.1)\end{array}$ & $\begin{array}{l}13.0 \\
(0.8)\end{array}$ \\
\hline & PINUS & sandy loam & $\begin{array}{l}6.4^{a} \\
(0.1)\end{array}$ & $\begin{array}{c}0.46 \\
(0.04)\end{array}$ & $\begin{array}{r}23.4^{a} \\
(0.6)\end{array}$ & $\begin{array}{l}6.1^{b} \\
(0.6)\end{array}$ & $\begin{array}{c}9.1 \\
(0.6)\end{array}$ & $\begin{array}{l}6.63^{a} \\
(0.47)\end{array}$ & $\begin{array}{l}3.3^{a} \\
(0.3)\end{array}$ & $\begin{array}{l}71^{c} \\
(3)\end{array}$ & $\begin{array}{l}0.26^{b} \\
(0.03)\end{array}$ & $\begin{array}{l}5.6^{b} \\
(0.2)\end{array}$ & $\begin{array}{l}12.7 \\
(1.5)\end{array}$ \\
\hline \multirow{3}{*}{$20-30$} & SGFOR & sandy loam & $\begin{array}{l}6.3^{a} \\
(0.1)\end{array}$ & $\begin{array}{c}0.52 \\
(0.05)\end{array}$ & $\begin{array}{c}22.3^{b} \\
(0.5)\end{array}$ & $\begin{array}{l}4.3^{b} \\
(0.7)\end{array}$ & $\begin{array}{l}11.8 \\
(0.8)\end{array}$ & $\begin{array}{l}7.59^{a} \\
(0.28)\end{array}$ & $\begin{array}{l}3.4^{b} \\
(0.3)\end{array}$ & $\begin{array}{l}64^{b} \\
(9)\end{array}$ & $\begin{array}{l}0.21^{b} \\
(0.05)\end{array}$ & $\begin{array}{l}4.0^{b} \\
(1.0)\end{array}$ & $\begin{array}{l}16.1 \\
(2.2)\end{array}$ \\
\hline & GRASS & sandy loam & $5.8^{b}$ & $\begin{array}{c}0.60 \\
(0.08)\end{array}$ & $24.4^{a}$ & $\begin{array}{l}10.7^{a} \\
(06)\end{array}$ & $\begin{array}{c}9.0 \\
(0.1)\end{array}$ & $5.75^{b}$ & $5.8^{a}$ & $98^{a}$ & $0.44^{a}$ & $\begin{array}{c}7.3^{a} \\
(0.8)\end{array}$ & 13.4 \\
\hline & PINUS & sandy loam & $\begin{array}{l}6.7^{a} \\
(0.1)\end{array}$ & $\begin{array}{c}0.47 \\
(0.05)\end{array}$ & $\begin{array}{r}22.2^{b} \\
(0.4)\end{array}$ & $\begin{array}{l}3.9^{b} \\
(1.0)\end{array}$ & $\begin{array}{l}10.2 \\
(0.3)\end{array}$ & $\begin{array}{l}7.19^{a} \\
(0.38)\end{array}$ & $\begin{array}{l}2.4^{b} \\
(0.4)\end{array}$ & $\begin{array}{l}51^{b} \\
(7)\end{array}$ & $\begin{array}{l}0.18^{b} \\
(0.03)\end{array}$ & $\begin{array}{l}3.9^{b} \\
(0.6)\end{array}$ & $\begin{array}{l}13.1 \\
(1.0)\end{array}$ \\
\hline
\end{tabular}

$\rho_{b}=$ Bulk density

$\mathrm{Al}_{\mathrm{Ox}}=$ Ammonium oxalate extractable $\mathrm{Al}$ content

$\mathrm{Al}_{\text {py }}=$ Pyrophosphate extractable $\mathrm{Al}$ content

$\mathrm{Si}_{\mathrm{OX}}=$ Ammonium oxalate extractable Si content

Allophane $=$ Estimated allophane content

TC=Total carbon content

$\mathrm{TN}=$ Total nitrogen content

the $\mathrm{Al}$ and $\mathrm{Si}$ content of the solutions were determined with respectively ICP-OES (Inductive Coupled Plasma - Optical Emission Spectrometry) (VISTA-MPX CCD Simultaneous ICP-OES, Varian, USA), and AAS (SpectrAA 600, Varian, USA). Allophane contents were calculated using the formula proposed by Parfitt and Wilson (1985), and later simplified by Mizota and van Reeuwijk (1989):

$$
\text { Allophane }=100 \mathrm{Si}_{\mathrm{ox}} \times\left[23.4-5.1\left(\frac{\mathrm{Al}_{\mathrm{ox}}-\mathrm{Al}_{\mathrm{py}}}{\mathrm{Si}_{\mathrm{ox}}}\right)\right](\%)
$$

\subsection{Statistical analyses}

Statistical analyses were performed using SYSTAT version 10.0 (SPSS, USA). Statistical differences of means (95\% significance level) were distinguished using ANOVA (3 replicates) followed by a Duncan's multiple range post-hoc test. Paired samples T-tests were used to determine differences in $\mathrm{C}$ mineralization rates between LF and HF fractions.
Log transformation was used to improve normality and homoscedastisticy in the data when necessary. In case no homogeneity of variance was reached after log transformation, Tamhane's T2 test was used as post-hoc test. Correlations were determined by the Pearson's correlation factor.

\section{Results}

\subsection{Physico- chemical soil properties}

The chemical and physical properties of the soils are listed in Table 1. Averaged over the three soil layers, land use changes significantly affected SOC stocks with +31 and $-42 \%$ for the conversion from SGFOR to GRASS and GRASS to PINUS, respectively. The N content was highest in GRASS, followed by SGFOR and PINUS. Nitrogen stocks varied from 0.53 to $0.18 \mathrm{~kg} \mathrm{~m}^{-2}$. Fertilizer additions on the GRASS site are responsible for the higher $\mathrm{N}$ contents in this site. The bulk 


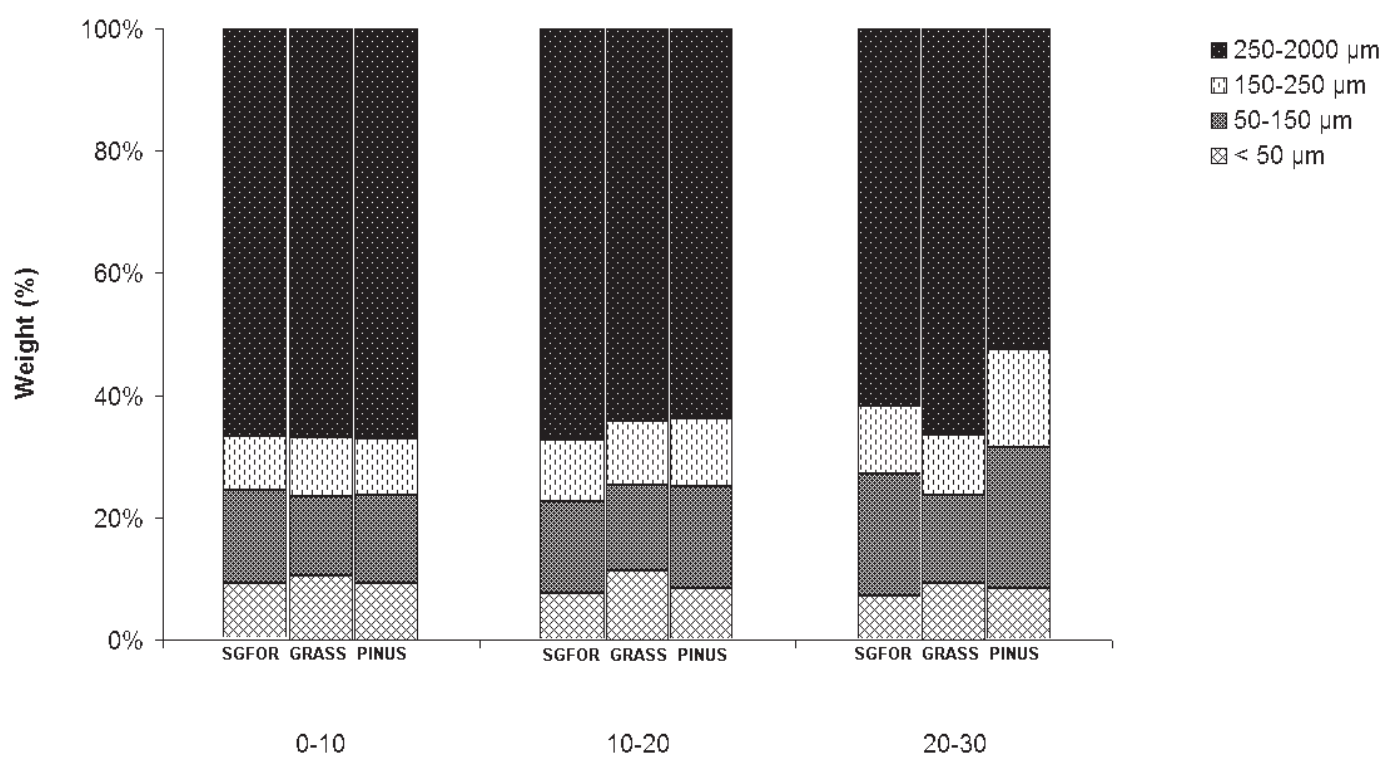

Fig. 2. Distribution of the soil weight over the different size classes (2000-250 $\mu \mathrm{m}, 250-150 \mu \mathrm{m}, 150-50 \mu \mathrm{m}$, and $<50 \mu \mathrm{m})$ after the first fractionation procedure (starting from "air-dried" soil) for the second growth forest (SGFOR), grassland (GRASS) and plantation (PINUS) and for the three soil layers $(0-10 \mathrm{~cm}, 10-20 \mathrm{~cm}$, and $20-30 \mathrm{~cm})$.



Fig. 3. Distribution of the soil weight over the different size classes (2000-250 $\mu \mathrm{m}, 250-150 \mu \mathrm{m}, 150-50 \mu \mathrm{m}$, and $<50 \mu \mathrm{m})$ after the second fractionation procedure (starting from field moist soil) for the second growth forest (SGFOR), grassland (GRASS) and plantation (PINUS) and for the three soil layers $(0-10 \mathrm{~cm}, 10-20 \mathrm{~cm}$, and $20-30 \mathrm{~cm})$.

density was higher in GRASS than in SGFOR and PINUS and is as well a result of agricultural livestock activities. Soil texture was categorized as sandy loam (USDA texture class) for all land use treatments. The soils in SGFOR and PINUS showed an average $\mathrm{pH}_{\mathrm{H}_{2} \mathrm{O}}$ between 6.1 and 6.7. In contrast, GRASS showed a lower $\mathrm{pH}_{\mathrm{H}_{2} \mathrm{O}}$ (around 5.5). The extractable $\mathrm{Al}_{\mathrm{Ox}}$ and $\mathrm{Al}_{\mathrm{py}}$ concentrations in the GRASS site were higher than for SGFOR and PINUS, though differences between GRASS and PINUS were not always significant for $\mathrm{Al}_{\mathrm{ox}}$. Soil $\mathrm{pH}$ was negatively correlated with $\mathrm{Al}_{\mathrm{ox}}(r=-0.45$; $p=0.02)$, and $\mathrm{Al}_{\text {py }}(r=-0.83 ; p=0.00)$. Allophane contents were, for all three soil layers, significantly lower for GRASS compared to SGFOR and PINUS. 
Table 2. Distribution of the soil weight according to the size fraction in Fig. 2 and Fig. 3, expressed as weighted average diameter (WAD), of the first and second fractionation procedure, and difference in WAD between the two fractionation procedures for the three soil layers of the second growth forest (SGFOR), grassland (GRASS), and plantation (PINUS) (Standard deviations between brackets, significant differences $(p<0.05)$ between land use treatments are indicated by different letters).

\begin{tabular}{lcccccccccc}
\hline & \multicolumn{3}{c}{$0-10 \mathrm{~cm}$} & \multicolumn{3}{c}{$10-20 \mathrm{~cm}$} & \multicolumn{3}{c}{$20-30 \mathrm{~cm}$} \\
\hline & SGFOR & GRASS & PINUS & SGFOR & GRASS & PINUS & SGFOR & GRASS & PINUS \\
\hline WAD first fractionation procedure $(\mu \mathrm{m})$ & $786^{A}$ & $788^{A}$ & $790^{A}$ & $794^{A}$ & $760^{A}$ & $758^{A}$ & $739^{A}$ & $785^{A}$ & $647^{B}$ \\
& $(40)$ & $(26)$ & $(13)$ & $(15)$ & $(27)$ & $(50)$ & $(19)$ & $(14)$ & $(34)$ \\
WAD second fractionation procedure $(\mu \mathrm{m})$ & $511^{A}$ & $662^{A}$ & $572^{A}$ & $522^{A}$ & $590^{A}$ & $585^{A}$ & $565^{B}$ & $720^{A}$ & $526^{B}$ \\
& $(118)$ & $(59)$ & $(124)$ & $(84)$ & $(73)$ & $(54)$ & $(33)$ & $(53)$ & $(5)$ \\
Difference in WAD $(\mu \mathrm{m})$ & $275^{A}$ & $126^{A}$ & $218^{A}$ & $273^{A}$ & $170^{A}$ & $173^{A}$ & $174^{A}$ & $65^{B}$ & $120^{A}, B$ \\
& $(84)$ & $(84)$ & $(125)$ & $(90)$ & $(97)$ & $(103)$ & $(25)$ & $(43)$ & $(34)$ \\
\hline
\end{tabular}

\subsection{Size and density fractionation of SOC}

The highest weight percentage after the first size fractionation was found in the size fraction $250-2000 \mu \mathrm{m}$ (Fig. 2). The other size fractions contain smaller amounts of soil weight, varying from 23.1 to $7.0 \%$ for all land use treatments. The WAD was not significantly different between the different land use treatments, except for PINUS $20-30 \mathrm{~cm}$ where a significant lower value was found (Table 2). TC concentration (\%) was not significantly different among the different size fractions in all the sites, with exception of the $0-10 \mathrm{~cm}$ layer of SGFOR (Table 3).

The results of the weight distribution of the second size fractionation experiment (after an 80 day incubation period, starting from field moist soil) are shown in Fig. 3. A considerable shift in soil weight towards the finer size fractions could be noticed, resulting in a smaller WAD compared to the first fractionation procedure (Table 2). Between land use treatments, GRASS showed the coarsest aggregate distribution but due to relative large standard deviations (on average $50 \mu \mathrm{m}$ ), differences in WAD were only significant for the 20 $30 \mathrm{~cm}$ layer. As in the first fractionation procedure, the TC concentration did not differ significantly among the different size classes for all land uses, though a few exceptions were observed here (data not shown).

Averaged over the three soil layers, the aggregate stability decreased in the following order: GRASS $>$ PINUS $>$ SGFOR. However, only significant differences were observed for the $20-30 \mathrm{~cm}$ layer between SGFOR and GRASS (Table 2). The difference in WAD was negatively correlated with the extractable $\mathrm{Al}_{\mathrm{Ox}}$ content of the soil $(r=-0.50 ; p=0.01)$, but not with the TC content $(r=-0.18 ; \quad p=0.38)$, extractable $\mathrm{Al}_{\text {py }}$ content $(r=-0.23$; $p=0.25)$ or allophane content $(r=0.11 ; p=0.60)$ of the soil. The relation between extractable $\mathrm{Al}_{\mathrm{ox}}$ content and difference in WAD for the different land use treatments and soil depths is given in Fig. 4.

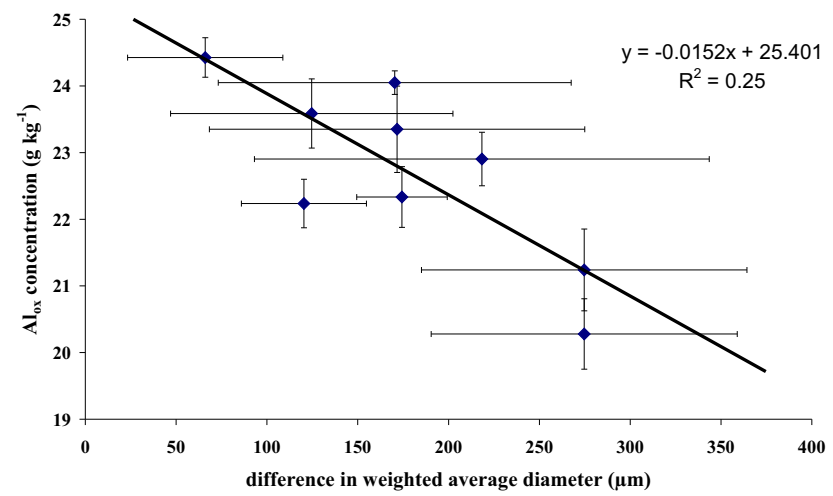

Fig. 4. The $\mathrm{Al}_{\mathrm{ox}}$ concentration in function of the difference in weighted average diameter for the different land use treatments and soil depths (error bars indicate plus/minus one standard deviation).

The amounts of MOM are expressed relative to the TC content (i.e. as \% of total C) (Table 4). The differences between land use treatments diminished with depth and were only significant between SGFOR, GRASS and PINUS for the $0-10 \mathrm{~cm}$ and $10-20 \mathrm{~cm}$ layer.

Table 5 shows the complete mass and SOC balance for the $0-10 \mathrm{~cm}$. It was found that the $\mathrm{C}$ content of the MOM is only a small fraction of the TC content $(2.4 \%-8.3 \%)$ in the soil. Though the concept of the fractionation procedure assumes that aggregates larger than $150 \mu \mathrm{m}$ are broken and the enclosed organic matter is released, still $56-74 \%$ of the total SOC content of the soil was found in the remaining mineral fraction (i.e. the fraction $150-2000 \mu \mathrm{m}$, from which the MOM is isolated).

\section{3 $\delta^{13} \mathrm{C}$ signature in size and density fractions}

The $\delta^{13} \mathrm{C}$ values of the whole SOC and the different size fractions in the three land use treatments and soil layers are presented in Table 6. Within the different size fractions of a 
Table 3. Carbon concentrations $\left(\mathrm{g} \mathrm{kg}^{-1}\right.$ ) for the soil layers of the second growth forest (SGFOR), grassland (GRASS), and plantation (PINUS) (Standard deviations between brackets, significant differences $(p<0.05)$ between aggregate size classes for a certain land use treatment and soil depth are indicated by different letters).

\begin{tabular}{|c|c|c|c|c|c|c|c|c|c|}
\hline & \multicolumn{9}{|c|}{ Carbon concentration $\left(\mathrm{g} \mathrm{kg}^{-1}\right)$} \\
\hline & \multicolumn{3}{|c|}{$0-10 \mathrm{~cm}$} & \multicolumn{3}{|c|}{$10-20 \mathrm{~cm}$} & \multicolumn{3}{|c|}{$20-30 \mathrm{~cm}$} \\
\hline & SGFOR & GRASS & PINUS & SGFOR & GRASS & PINUS & SGFOR & GRASS & PINUS \\
\hline $250 \mu \mathrm{m}-2000 \mu \mathrm{m}$ & $\begin{array}{c}141_{a, b} \\
(16)\end{array}$ & $\begin{array}{r}111_{a} \\
(13)\end{array}$ & $\begin{array}{l}93 a \\
(13)\end{array}$ & $\begin{array}{r}90 a \\
(6)\end{array}$ & $\begin{array}{c}105_{a} \\
(5)\end{array}$ & $\begin{array}{l}71_{a} \\
(15)\end{array}$ & $\begin{array}{l}66_{a} \\
(6)\end{array}$ & $\begin{array}{r}98_{a} \\
(9)\end{array}$ & $\begin{array}{l}52 a \\
(8)\end{array}$ \\
\hline $150 \mu \mathrm{m}-250 \mu \mathrm{m}$ & $\begin{array}{c}146_{a} \\
(7)\end{array}$ & $\begin{array}{r}111_{a} \\
(17)\end{array}$ & $\begin{array}{l}98_{a} \\
(12)\end{array}$ & $\begin{array}{c}88_{a} \\
(6)\end{array}$ & $\begin{array}{c}106_{a} \\
(1)\end{array}$ & $\begin{array}{l}69 a \\
(13)\end{array}$ & $\begin{array}{l}63_{a} \\
(11)\end{array}$ & $\begin{array}{l}99 a \\
(7)\end{array}$ & $\begin{array}{l}50_{a} \\
(7)\end{array}$ \\
\hline $50 \mu \mathrm{m}-150 \mu \mathrm{m}$ & $\begin{array}{c}148_{a} \\
(19)\end{array}$ & $\begin{array}{c}107 a \\
\text { (19) }\end{array}$ & $\begin{array}{l}99 a \\
(14)\end{array}$ & $\begin{array}{r}93 a \\
(3)\end{array}$ & $\begin{array}{c}105_{a} \\
(4)\end{array}$ & $\begin{array}{l}72 a \\
(10)\end{array}$ & $\begin{array}{l}67 a \\
(10)\end{array}$ & $\begin{array}{l}97 a \\
(6)\end{array}$ & $\begin{array}{l}52_{a} \\
(7)\end{array}$ \\
\hline$<50 \mu \mathrm{m}$ & $\begin{array}{c}122_{b} \\
(5)\end{array}$ & $\begin{array}{l}110_{a} \\
(15)\end{array}$ & $\begin{array}{l}84_{a} \\
(12)\end{array}$ & $\begin{array}{l}81_{a} \\
(2)\end{array}$ & $\begin{array}{c}106_{a} \\
(2)\end{array}$ & $\begin{array}{c}68_{a} \\
(6)\end{array}$ & $\begin{array}{l}61_{a} \\
(8)\end{array}$ & $\begin{array}{r}96_{a} \\
(4)\end{array}$ & $\begin{array}{l}48_{a} \\
(6)\end{array}$ \\
\hline
\end{tabular}

Table 4. Percentage of total $\mathrm{C}$ of the macro organic matter fractions (MOM) for the second growth forest (SGFOR), grassland (GRASS) and plantation (PINUS) (Standard deviations between brackets, significant differences between land use treatments in the same soil layer are indicated by different letters).

\begin{tabular}{cccccccc}
\hline Soil layer $(\mathrm{cm})$ & & \multicolumn{5}{c}{$\%$ of total C } \\
\hline \multirow{2}{*}{$0-10$} & Macro organic matter & $8.3^{A}$ & $(1.9)$ & $2.4^{B}$ & $(0.5)$ & $5.0^{C}$ & $(0.8)$ \\
& HF & $0.8^{A}$ & $(0.1)$ & $0.4^{B}$ & $(0.0)$ & $1.1^{A}$ & $(0.3)$ \\
& IF & $1.0^{A}$ & $(0.1)$ & $0.3^{B}$ & $(0.0)$ & $0.8^{C}$ & $(0.1)$ \\
& LF & $6.5^{A}$ & $(1.9)$ & $1.7^{B}$ & $(0.5)$ & $3.1^{B}$ & $(0.7)$ \\
$10-20$ & Macro organic matter & $2.8^{A}$ & $(0.6)$ & $1.6^{B}$ & $(0.1)$ & $3.6^{C}$ & $(0.2)$ \\
& HF & $0.3^{A}$ & $(0.1)$ & $0.3^{A}$ & $(0.0)$ & $0.8^{B}$ & $(0.1)$ \\
& IF & $0.4^{A}$ & $(0.2)$ & $0.2^{A}$ & $(0.1)$ & $0.7^{B}$ & $(0.2)$ \\
& LF & $2.1^{A}$ & $(0.3)$ & $1.1^{B}$ & $(0.1)$ & $2.1^{A}$ & $(0.3)$ \\
& Macro organic matter & $3.8^{A}$ & $(1.4)$ & $1.1^{B}$ & $(0.1)$ & $3.4^{A}$ & $(0.5)$ \\
& HF & $0.4^{A}$ & $(0.2)$ & $0.3^{A}$ & $(0.0)$ & $1.0^{B}$ & $(0.2)$ \\
& IF & $0.7^{A}$ & $(0.3)$ & $0.1^{B}$ & $(0.1)$ & $0.8^{A}$ & $(0.2)$ \\
& LF & $2.7^{A}$ & $(0.9)$ & $0.6^{B}$ & $(0.1)$ & $1.6^{A, B}$ & $(0.4)$ \\
\hline
\end{tabular}

$\mathrm{HF}=$ Heavy density fraction (density $>1.37 \mathrm{Mg} \mathrm{m}^{-3}$ )

$\mathrm{IF}=$ Intermediate density fraction $\left(1.13 \mathrm{Mg} \mathrm{m}^{-3}<\right.$ density $\left.<1.37 \mathrm{Mg} \mathrm{m}^{-3}\right)$

$\mathrm{LF}=$ Light density fraction (density $<1.13 \mathrm{Mg} \mathrm{m}^{-3}$ )

certain land use, no significant differences in $\delta^{13} \mathrm{C}$ value were found. However, a significant difference of 1-2\%o was found between the $\delta^{13} \mathrm{C}$ value of the size classes and MOM density classes for the different land use treatments, with exception for PINUS $0-10 \mathrm{~cm}$.

\subsection{C mineralization experiments}

\subsubsection{Whole soil C mineralization}

The cumulative $\mathrm{C}$ mineralization curves were calculated for all land use treatments as shown in Fig. 5 for SGFOR. The linear part of each curve (from day 17 to 62 ) was used to estimate the potential $\mathrm{C}$ mineralization rate via linear regression (Table 7). The differences in potential $\mathrm{C}$ mineralization rates between the different land use treatments were significant in the $0-10 \mathrm{~cm}$ soil layer: SGFOR $>$ PINUS $>$ GRASS. However, differences between the three land use treatments disappeared gradually with depth. In the $10-20 \mathrm{~cm}$ and 20 $30 \mathrm{~cm}$ layer SGFOR still showed the highest potential mineralization rate, but differences were no longer significant. For all land use treatments, potential $\mathrm{C}$ mineralization rates decreased with soil depth. The $\mathrm{C}$ mineralization rate constant, 
Table 5. Weight, C concentration, and \% of total $\mathrm{C}$ of the different soil organic carbon fractions for the second growth forest (SGFOR), grassland (GRASS) and plantation (PINUS) for the $0-10 \mathrm{~cm}$ soil layer (Standard deviations between brackets, significant differences $(p<0.05)$ between land use treatments are indicated by different letters).

\begin{tabular}{lcccccccccc}
\hline & \multicolumn{3}{c}{$\begin{array}{c}\text { Weight } \\
\left(\mathrm{g} \mathrm{kg}^{-1} \text { soil }\right)\end{array}$} & \multicolumn{3}{c}{$\begin{array}{c}\text { C-concentration } \\
\left(\mathrm{g} \mathrm{C} \mathrm{kg}^{-1} \text { fraction }\right)\end{array}$} & \multicolumn{3}{c}{$\begin{array}{c}\text { \% of total C } \\
(\%)\end{array}$} \\
\hline & NO & GR & PR & NO & GR & PR & NO & GR & PR \\
\hline Whole soil & 1000 & 1000 & 1000 & $139^{A}$ & $111^{B}$ & $94^{C}$ & & & \\
& & & & $(7)$ & $(1)$ & $(6)$ & & & \\
SOC fractions & & & & & & & & & \\
MOM & $31.5^{A}$ & $8.6^{B}$ & $14.4^{B}$ & $366^{A}$ & $309^{B}$ & $325^{B}$ & $8.3^{A}$ & $2.4^{B}$ & $5.0^{C}$ \\
& $(5.8)$ & $(1.8)$ & $(2.8)$ & $(5)$ & $(12)$ & $(32)$ & $(1.9)$ & $(0.5)$ & $(0.8)$ \\
HF & $4.6^{A}$ & $1.7^{B}$ & $4.5^{A}$ & $239^{A}$ & $251^{A}$ & $230^{A}$ & $0.8^{A}$ & $0.4^{B}$ & $1.1^{A}$ \\
& $(0.4)$ & $(0.1)$ & $(1.6)$ & $(28)$ & $(8)$ & $(34)$ & $(0.1)$ & $(0.0)$ & $(0.3)$ \\
IF & $4.5^{A}$ & $1.1^{C}$ & $2.4^{B}$ & $328^{A}$ & $284^{A}$ & $305^{A}$ & $1.0^{A}$ & $0.3^{C}$ & $0.8^{B}$ \\
& $(0.1)$ & $(0.2)$ & $(0.6)$ & $(20)$ & $(18)$ & $(47)$ & $(0.1)$ & $(0.0)$ & $(0.1)$ \\
LF & $22.5^{A}$ & $5.8^{C}$ & $7.6^{B}$ & $399^{A}$ & $332^{B}$ & $385^{A}$ & $6.5^{A}$ & $1.7^{B}$ & $3.1^{B}$ \\
& $(5.5)$ & $(1.7)$ & $(1.5)$ & $(5)$ & $(16)$ & $(14)$ & $(1.9)$ & $(0.5)$ & $(0.7)$ \\
Mineral fraction & $738^{A}$ & $756^{A}$ & $749^{A}$ & $108^{A}$ & $109^{A}$ & $90^{B}$ & $56.4^{A}$ & $74.4^{B}$ & $71.5^{B}$ \\
$150 \mu \mathrm{m}-2000 \mu \mathrm{m}$ & $(28)$ & $(16)$ & $(8)$ & $(11)$ & $(9)$ & $(3)$ & $(3.8)$ & $(3.2)$ & $(4.3)$ \\
$50-150 \mu \mathrm{m}$ & $152^{A}$ & $130^{A}$ & $143^{A}$ & $149^{A}$ & $107^{B}$ & $99^{B}$ & $16.7^{A}$ & $12.5^{A}$ & $15.0^{A}$ \\
& $(40)$ & $(23)$ & $(9)$ & $(19)$ & $(4)$ & $(10)$ & $(6.3)$ & $(1.8)$ & $(0.9)$ \\
$<50 \mu \mathrm{m}$ & $91^{A}$ & $104^{A}$ & $93^{A}$ & $122^{A}$ & $110^{A}$ & $84^{B}$ & $7.9^{A}$ & $10.3^{B}$ & $8.3^{A, B}$ \\
\multirow{2}{*}{ Sum of the fractions } & $(15)$ & $(6)$ & $(14)$ & $(5)$ & $(2)$ & $(8)$ & $(0.7)$ & $(0.7)$ & $(1.7)$ \\
& & & & & & & $89.5^{A}$ & $99.6^{A}$ & $99.7^{A}$ \\
& & & & & & & $(8.2)$ & $(3.6)$ & $(5.5)$ \\
\hline
\end{tabular}

SOC=Soil organic carbon

MOM=Macro organic matter $(>150 \mu \mathrm{m})$

$\mathrm{HF}=$ Heavy density fraction $\left(\right.$ density $>1.37 \mathrm{Mg} \mathrm{m}^{-3}$ )

$\mathrm{IF}=$ Intermediate density fraction $\left(1.13 \mathrm{Mg} \mathrm{m}^{-3}<\right.$ density $\left.<1.37 \mathrm{Mg} \mathrm{m}^{-3}\right)$

$\mathrm{LF}=$ Light density fraction (density $<1.13 \mathrm{Mg} \mathrm{m}^{-3}$ )

which can be used as an indicator of the degradability of the SOC, was calculated by dividing the observed potential C mineralization rate (expressed per gram soil) by the corresponding TC content in each soil layer (Table 7). For the $0-10 \mathrm{~cm}$ soil layer, these values varied from 0.029 for SGFOR to 0.023 for PINUS and $0.011 \mathrm{yr}^{-1}$ for GRASS. In all soil layers, the decomposability of the SOC was significantly lower for GRASS than for PINUS and SGFOR. The SOC from GRASS showed the highest stability against microbial breakdown. Statistical correlation tests showed that the $\mathrm{C}$ mineralization rate constants were significantly correlated with the difference in WAD $(r=0.39 ; p=0.04)$ and the extractable $\mathrm{Al}_{\mathrm{Ox}}$ content $(r=-0.68 ; p=0.00)$.

\subsubsection{Incubation of the isolated MOM density fractions HF and $\mathrm{LF}$}

In this procedure, the MOM was isolated by the density separation procedure, through which the physical protection of SOC in soil aggregates could be removed (Fig. 1).

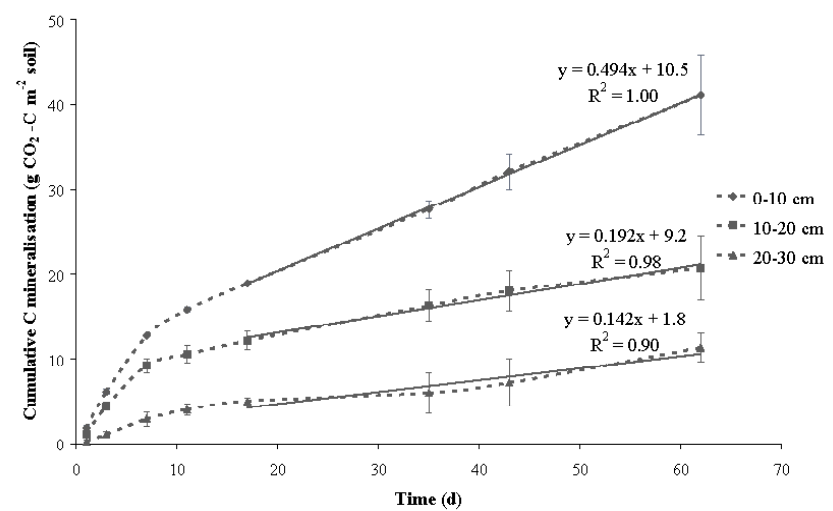

Fig. 5. Evolution of the cumulative $\mathrm{C}$ mineralization for the second growth forest (SGFOR) for the $0-10 \mathrm{~cm}, 10-20 \mathrm{~cm}$ and $20-30 \mathrm{~cm}$ soil layer (day 1 to day 62) (error bars indicate plus/minus one standard deviation), and linear regression of the curves (from day 17 to day 62). 
Table 6. $\delta^{13} \mathrm{C}$ values (\%o) of the soil organic carbon fractions for the second growth forest (SGFOR), grassland (GRASS) and plantation (PINUS) (Standard deviations between brackets, significant differences $(p<0.05)$ between soil organic carbon fractions are indicated by different letters).

\begin{tabular}{|c|c|c|c|c|c|c|c|c|c|}
\hline \multirow{3}{*}{ Fraction } & \multicolumn{9}{|c|}{$\delta^{13} \mathrm{C}(\% \circ)$} \\
\hline & \multicolumn{3}{|c|}{$0-10 \mathrm{~cm}$} & \multicolumn{3}{|c|}{$10-20 \mathrm{~cm}$} & \multicolumn{3}{|c|}{$20-30 \mathrm{~cm}$} \\
\hline & SGFOR & GRASS & PINUS & SGFOR & GRASS & PINUS & SGFOR & GRASS & PINUS \\
\hline Whole soil & $\begin{array}{c}-27.2 \\
(0.1)\end{array}$ & $\begin{array}{l}-26.7 \\
(0.3)\end{array}$ & $\begin{array}{l}-27.8 \\
(0.2)\end{array}$ & $\begin{array}{l}-26.4 \\
(0.4)\end{array}$ & $\begin{array}{l}-26.8 \\
(0.1)\end{array}$ & $\begin{array}{l}-26.7 \\
(0.2)\end{array}$ & $\begin{array}{l}-26.2 \\
(0.2)\end{array}$ & $\begin{array}{c}-26.7 \\
(0.3)\end{array}$ & $\begin{array}{c}-26.4 \\
(0.1)\end{array}$ \\
\hline Macro organic matter & $\begin{array}{c}-28.3 b \\
(0.4)\end{array}$ & $\begin{array}{c}-28.7_{b} \\
(0.6)\end{array}$ & $\begin{array}{c}-29.2_{b} \\
(0.6)\end{array}$ & $\begin{array}{c}-27.7_{b} \\
(0.1)\end{array}$ & $\begin{array}{c}-27.8_{b} \\
(0.1)\end{array}$ & $\begin{array}{c}-28.2_{b} \\
(0.3)\end{array}$ & $\begin{array}{c}-27.7_{b} \\
(0.1)\end{array}$ & $\begin{array}{c}-27.5_{b} \\
(0.3)\end{array}$ & $\begin{array}{c}-28.2 b \\
(0.2)\end{array}$ \\
\hline \multicolumn{10}{|l|}{ Size fractions } \\
\hline $250 \mu \mathrm{m}-2000 \mu \mathrm{m}$ & $\begin{array}{c}-27.2_{a} \\
(0.1)\end{array}$ & $\begin{array}{c}-26.7 a \\
(0.6)\end{array}$ & $\begin{array}{c}-27.9 a \\
(0.6)\end{array}$ & $\begin{array}{c}-26.4_{a} \\
(0.4)\end{array}$ & $\begin{array}{c}-26.8_{a} \\
(0.1)\end{array}$ & $\begin{array}{c}-26.7_{a} \\
(0.2)\end{array}$ & $\begin{array}{c}-26.3_{a} \\
(0.2)\end{array}$ & $\begin{array}{c}-26.7 a \\
(0.4)\end{array}$ & $\begin{array}{c}-26.4 a \\
(0.1)\end{array}$ \\
\hline $150 \mu \mathrm{m}-250 \mu \mathrm{m}$ & $\begin{array}{c}-27.2_{a} \\
(0.2)\end{array}$ & $\begin{array}{c}-26.7 a \\
(0.5)\end{array}$ & $\begin{array}{c}-27.9 a \\
(0.6)\end{array}$ & $\begin{array}{c}-26.4 a \\
(0.4)\end{array}$ & $\begin{array}{c}-26.8_{a} \\
(0.1)\end{array}$ & $\begin{array}{c}-26.7_{a} \\
(0.1)\end{array}$ & $\begin{array}{c}-26.2_{a} \\
(0.3)\end{array}$ & $\begin{array}{c}-26.7 a \\
(0.3)\end{array}$ & $\begin{array}{c}-26.3 a \\
(0.2)\end{array}$ \\
\hline $50 \mu \mathrm{m}-150 \mu \mathrm{m}$ & $\begin{array}{c}-27.1_{a} \\
(0.2)\end{array}$ & $\begin{array}{c}-26.6_{a} \\
(0.7)\end{array}$ & $\begin{array}{c}-27.7 a \\
(0.7)\end{array}$ & $\begin{array}{c}-26.4 a \\
(0.4)\end{array}$ & $\begin{array}{c}-26.8_{a} \\
(0.1)\end{array}$ & $\begin{array}{c}-26.7_{a} \\
(0.1)\end{array}$ & $\begin{array}{c}-26.2_{a} \\
(0.2)\end{array}$ & $\begin{array}{c}-26.7 a \\
(0.3)\end{array}$ & $\begin{array}{c}-26.3 a \\
(0.2)\end{array}$ \\
\hline$<50 \mu \mathrm{m}$ & $\begin{array}{c}-27.2_{a} \\
(0.2)\end{array}$ & $\begin{array}{c}-26.7 a \\
(0.6)\end{array}$ & $\begin{array}{c}-27.7 a \\
(0.7)\end{array}$ & $\begin{array}{c}-26.4 a \\
(0.3)\end{array}$ & $\begin{array}{c}-26.8_{a} \\
(0.1)\end{array}$ & $\begin{array}{c}-26.7_{a} \\
(0.1)\end{array}$ & $\begin{array}{c}-26.1_{a} \\
(0.3)\end{array}$ & $\begin{array}{c}-26.6_{a} \\
(0.1)\end{array}$ & $\begin{array}{c}-26.2_{a} \\
(0.1)\end{array}$ \\
\hline
\end{tabular}

Table 7. Potential C mineralization rates and decomposition rate constants for the second growth forest (SGFOR), grassland (GRASS) and plantation (PINUS) for 0-10 cm, 10-20 cm and 20-30 cm soil layer (Standard deviation between brackets, significant differences between land use treatments $(p<0.05)$ are indicated by different letters).

\begin{tabular}{ccccccc}
\hline Land use class & \multicolumn{3}{c}{ Potential mineralization rate } & \multicolumn{3}{c}{ Mineralization rate constant } \\
\hline \multirow{3}{*}{ SGFOR } & $0-10 \mathrm{~cm}$ & $10-20 \mathrm{~cm}$ & $20-30 \mathrm{~cm}$ & $0-10 \mathrm{~cm}$ & $10-20 \mathrm{~cm}$ & $20-30 \mathrm{~cm}$ \\
\hline \multirow{3}{*}{$\mathrm{g} \mathrm{CO}_{2^{-}-\mathrm{C} \mathrm{m}^{-2} \mathrm{~d}^{-1}}$} & - & $\mathrm{yr}^{-1}$ & - \\
GRASS & $0.495^{a}$ & $0.192^{a}$ & $0.142^{a}$ & $0.029^{a}$ & $0.017^{a}$ & $0.018^{a}$ \\
& $(0.108)$ & $(0.061)$ & $(0.041)$ & $(0.005)$ & $(0.005)$ & $(0.003)$ \\
\multirow{2}{*}{ PINUS } & $0.196^{c}$ & $0.092^{a}$ & $0.087^{a}$ & $0.011^{b}$ & $0.005^{b}$ & $0.005^{b}$ \\
& $(0.021)$ & $(0.021)$ & $(0.034)$ & $(0.001)$ & $(0.001)$ & $(0.002)$ \\
& $0.266^{b}$ & $0.135^{a}$ & $0.087^{a}$ & $0.023^{a}$ & $0.015^{a}$ & $0.014^{a}$ \\
& $(0.041)$ & $(0.034)$ & $(0.044)$ & $(0.001)$ & $(0.008)$ & $(0.006)$ \\
\hline
\end{tabular}

Especially, the accessibility of the HF has been increased, as this fraction is more associated with soil minerals and components compared to the LF. The LF is mainly present in the soil as free MOM. Only a small fraction is bounded in soil aggregates (Hassink, 1995; Swanston et al., 2002). Potential $\mathrm{C}$ mineralization rates and $\mathrm{C}$ mineralization rate constants of the isolated density fractions were calculated using the same method as the whole soil $\mathrm{C}$ mineralization experiment (Table 8). In this experiment, the mineralization rate constants are an indicator of the recalcitrance of the MOM fractions. Statistical analyses showed that the potential $\mathrm{C}$ mineralization rates of the LF and HF were significantly different for all land use treatments. The $\mathrm{C}$ mineralization rate constants of the LF and HF are significantly different for GRASS, but not for SGFOR and PINUS.
The $\mathrm{C}$ mineralization rate constants showed that the MOM from GRASS decomposes fastest. The recalcitrance of the LF decreased in the following order: PINUS $>$ SGFOR $>$ GRASS. For the HF, PINUS showed a higher recalcitrance than GRASS, whereas the value of SGFOR was not significantly different from PINUS and GRASS (Table 8).

\section{Discussion}

In a first section of the discussion, we will focus on the interaction of $\mathrm{Al}, \mathrm{SOC}$ and soil minerals. The potential role of Al-humus complexes and electrostatic- $\mathrm{C}$ binding on aggregate structure will be assessed in this Andisol. In a second 
Table 8. Potential mineralization rates and mineralization rate constants of the light (LF) and heavy (HF) density fraction for the second growth forest (SGFOR), grassland (GRASS) and plantation (PINUS) (Standard deviations between brackets, significant differences $(p<0.05)$ are indicated by different letters (upper case letters between LF and HF, lower case letters between land use treatments)).

\begin{tabular}{ccccc}
\hline Land use class & \multicolumn{2}{c}{ Potential mineralization rate } & \multicolumn{2}{c}{ Mineralization rate constant } \\
\hline & $\mathrm{LF}$ & $\mathrm{HF}$ & $\mathrm{LF}$ & $\mathrm{HF}$ \\
\hline & \multicolumn{2}{c}{$\mathrm{mg} \mathrm{CO}_{2}-\mathrm{C} \mathrm{kg}^{-1}$ fraction d $^{-1}$} & \multicolumn{2}{c}{$\mathrm{yr}^{-1}$} \\
\hline \multirow{2}{*}{ SGFOR } & $131.2_{a}^{A}$ & $59.7_{a, b}^{B}$ & $0.120_{a}^{A}$ & $0.090_{a, b}^{A}$ \\
& $(11.4)$ & $(14.6)$ & $(0.010)$ & $(0.022)$ \\
GRASS & $137.4_{a}^{A}$ & $73.0_{a}^{B}$ & $0.151_{b}^{A}$ & $0.106_{a}^{B}$ \\
& $(6.2)$ & $(7.6)$ & $(0.007)$ & $(0.011)$ \\
PINUS & $74.7_{b}^{A}$ & $37.6_{b}^{B}$ & $0.071_{c}^{A}$ & $0.060_{b}^{A}$ \\
& $(14.2)$ & $(8.4)$ & $(0.013)$ & $(0.013)$ \\
\hline
\end{tabular}

part, we will evaluate the results of $\mathrm{C}$ mineralization experiments. In a third section, a link between aggregate structure, $\mathrm{C}$ mineralization and SOC stabilization will be made. In a last section, the potential role of $\mathrm{pH}$ on aggregate structure and SOC stabilization will be discussed.

\subsection{Aggregate structure in south Chilean Andisols}

In literature, two main sorption mechanisms are documented in $\mathrm{Al}$ rich soils. As sorption tends to promote aggregation (Sollins et al., 1996), these mechanisms lead to aggregate build up and might be responsible for the occurrence of high amounts of water-stable aggregates in this soil type (e.g. Hoyos and Comerford, 2005; see Sect. 3.2). Firstly, metalhumus complexes would act as binding agents between aggregates or soil particles. In metal-humus complexes, SOC can be sorbed by allophane through ligand exchange between functional groups of SOC and Al (Parfitt et al., 1977; Skjemstad, 1992; Parfitt et al., 1999). In this mechanism, an organic ligand replaces a hydroxyl group, which is coordinated to the metal ion on the surface of the oxide to form a surface complex. Since surface hydroxyls are characteristic for variable charge surfaces, sorption of negatively charged organics by ligand exchange should be most important in oxide-rich and allophanic soils, such as Andisols (Sollins et al., 1996). Other bounding types involved in sorption between SOC and metals include cation bridging (Varadachari et al., 1995), water bridging, hydrogen bounding, and van der Waals forces (Burchill et al., 1981). However, distinction between potential types is impossible bearing in mind the methodology of this study. In this first case, the mechanism of aggregate hierarchy (Tisdall and Oades, 1982) would be adequate to describe $\mathrm{C}$ dynamics as $\mathrm{SOC}$ (bonded to $\mathrm{Al}$ ) acts as principal binding agent between soil components.

Secondly, electrostatic attractions could occur between and among amorphous Al components and clay minerals due to the simultaneous existence of positive and negative charges at field pH (Schofield and Samson, 1954; El-Swaify,
1980; Six et al., 2000b; Six et al., 2000c; Denef et al., 2002). Thus, here aggregate formation is partly induced by electrostatic interactions between soil minerals and $\mathrm{Al}$ components and aggregate hierarchy should be less pronounced (Oades and Waters, 1991).

We conceptually tested the occurrence of aggregate hierarchy for the different land use treatments. Three consequences of this theory are: (1) a gradual breakdown of macroaggregates into microaggregates before they dissolve into primary particles, as increasing dispersive energy is applied to the soil (Oades and Waters, 1991), (2) an increase in percentage $\mathrm{C}$ concentration with increasing aggregate-size class because large aggregate-size classes are composed of small aggregate-size classes plus organic binding agents (Elliott, 1986), and (3) younger and more labile organic matter is contained in macroaggregates rather than in microaggregates (Elliott, 1986; Puget et al., 1995; Jastrow et al., 1996). Firstly, the fractionation of the soils at two different periods allowed us to test the aggregate stability. A gradual breakdown of macroaggregates into microaggregates could be observed (Figs. 2, 3). It was shown that this breakdown could not be explained by the TC content, allophane content or extractable $\mathrm{Al}_{\mathrm{py}}$ content of the soil, but by the extractable $\mathrm{Al}_{\mathrm{ox}}$ content of the soil (Fig. 4). In the latter Al-extraction procedure, only amorphous and poorly crystalline Al-oxides and Al bound to organic complexes could be isolated (Bertsch and Bloom, 1996). Secondly, the TC concentration did not differ among the different size classes for a certain land use treatment (Table 3). Absence of differences in $\mathrm{C}$ concentration between aggregate-size classes in Andisols was also documented by Hoyos and Comerford (2005). Thirdly, there were no significant differences in $\delta^{13} \mathrm{C}$ values among the different size classes for a certain soil (Table 6). In contrast to e.g. Accoe et al. (2002), no gradual shift in $\delta^{13} \mathrm{C}$ value towards finer aggregate classes could be observed as a result of increasing decomposition (O'Brien and Stout, 1978). In this study, we could only distinguish two different SOC pools: the MOM and the mineral soil pool. It was indicated that the 
SOC in the different size fractions is at the same degree of decomposition.

The results of these experiments indicated that metalhumus complexes are probably not the main binding agents between soil aggregates in these Andisols. Aggregate buildup would be mainly a result of electrostatic attractions between and among $\mathrm{Al}$ and $\mathrm{Al}$-oxides and clay minerals, as documented as well by Schofield and Samson (1954), Violante and Huang (1992) and Denef et al. (2002). SOC would only play a minor role in these strong bindings between larger aggregates. Absence of aggregate hierarchy in this soil type has earlier been documented by Hoyos and Comerford (2005).

On the other hand, ploughing (Beare et al., 1994; Six et al., 1999) and drying of the soil might influence the aggregate structure. Every two year, the GRASS site is disturbed by ploughing. Drying of Andisols might cause dramatic changes of the physical properties of aggregates, and lead to a coarser aggregate size distribution (Shoji et al., 1993). Even air-drying can affect the particle size and microaggregate distribution. Tillage on the GRASS site might have exposed the soil unprotected to the sun and resulted in drying of the topsoil layer, leading to an increase in stable aggregates. Continued ploughing would lead to a mixture of the aggregates in the upper $30 \mathrm{~cm}$ of the soil.

\subsection{C mineralization experiments}

Land use changes affect SOC dynamics by differences in SOC input, and by direct effects of accompanying soil disturbances (Guo and Gifford, 2002). Pastures maintain a continuous vegetation cover on the soil and have high turnover rates and productivity, particularly belowground. As a result more intense humus formation would take place (Brown and Lugo, 1990; Yakimenko, 1998). Jobbagy and Jackson (2000) indicated that the annual turnover of SOC from dying tree roots is smaller than from grass roots. In forested ecosystems, the SOC inputs originate partly from aboveground and accumulate more in and on the surface soil due to non-mixing of the litter (Paul et al., 2002). SOC tends to decompose partly before it is incorporated into the forest soil, involving a smaller formation of SOC. Thus, under grassland a thicker A horizon is formed compared with forests (e.g. Birkland, 1984). According to Guo and Gifford (2002), the lower SOC content in plantations may partly be attributed to soil disturbances and consequent loss in physical protection of the SOC involved in the establishment of plantations. The transformation from a multi-storey forest to a single storey plantation lacking understorey vegetation results in less SOC input (Guo and Gifford, 2002). Also, during the first years after the establishment of a plantation, reduced SOC sequestration takes place as a result of low SOC input (due to a small forest biomass and low litter fall rate) (Wilde, 1964) and a continued decomposition of the SOC present in the soil profile. Carbon storage as well is affected by forest type (species, deciduous, evergreen) (Lal et al., 1995).

In our study, the whole soil $\mathrm{C}$ mineralization rate constant decreased in the following order: $\mathrm{SGFOR} \approx \mathrm{PINUS}>$ GRASS. Our values are in accordance to those found in Columbian Andisols by Boudot et al. (1986), who measured a mineralization rate constant of approximately $0.01 \mathrm{yr}^{-1}$ in the $5-20 \mathrm{~cm}$ layer. Based on the $\mathrm{C}$ mineralization rate constants of the incubated MOM fractions, we were able to distinguish differences in the recalcitrance of the SOC of the different land use treatments (see below).

\subsection{Evaluation of SOC stabilization mechanisms}

As stated by Sollins et al. (1996), SOC can be stabilized by different mechanisms. We will consider each factor or process that controls the rate of stabilization, and discuss its potential effects on SOC stabilization in our soils. Sollins (1996) brought forward following sets of characteristics affecting the stability of SOC: recalcitrance, interactions and accessibility. Though we mainly focus on the aspect of accessibility, one has to bear in mind that several mechanisms and processes interact to determine the stability or biodegradability of SOC in soils (Marschner and Kalbitz, 2003). Keeping in mind the used methodology of this study, we cannot deduce conclusions on all aspects. In order to assess the importance of certain mechanisms, we will refer to the state-of-the-art in literature.

\section{Recalcitrance}

We tried to assess the importance of this parameter for the studied land use treatments by performing mineralization experiments of the isolated MOM fractions. We encountered that the degree of the whole soil $\mathrm{C}$ mineralization rate constants was opposite to the degree of the $\mathrm{C}$ mineralization rate constants of the isolated MOM fractions. Therefore, recalcitrance of the SOC did not appear to control SOC stabilization. Thus, other stabilization mechanisms should overrule the influence of litter quality on whole soil $\mathrm{C}$ mineralization rates.

\section{Interactions between soil components}

We showed that in our soils, $\mathrm{Al}$ is associated to clay minerals by electrostatic sorption. These clay minerals are associated to SOC, leading to the formation of metalhumus-clay complexes. Direct adsorption of SOC to Al by ligand exchange is considered of minor importance in our soils. Many studies (e.g. Percival et al., 2000) assume ligand exchange to be very important in Andisols, based on data of pyrophosphate extractable $\mathrm{Al}$. In the literature (Bertsch and Bloom, 1996), the extractable $\mathrm{Al}_{\text {py }}$ content is often related to the directly organically bound $\mathrm{Al}$, while the 
quantity of poorly ordered amorphous or noncrystalline $\mathrm{Al}$ phases plus the organically bound $\mathrm{Al}$ would be proportional to $\mathrm{Al}_{\mathrm{ox}}$. However, we believe that in a very close association between SOC, Al and soil minerals, as occurring in our soils, extractants cannot be completely selective for one certain phase. This as well was brought forward by Bertsch and Bloom (1996). Kaiser and Zech (1996) indicated that pyrophosphate also removed $\mathrm{Al}$ hydroxides and stated that it should not be used to estimate $\mathrm{Al}$ in humus complexes.

The formation of metal-humus-clay complexes by sorption onto clay minerals is usually assumed to stabilize SOC. It is known that such metal-humus-clay complexes are resistant to microbial decomposition (Juste et al., 1975; Martin et al., 1982) in Andisols. These adsorption reactions would provide a mechanism of stabilizing SOC against biological attack (Baldock and Skjemstad, 2000). However, the relevance of SOC stabilization remains poorly understood (Sollins et al., 1996). Sollins et al. (1996) indicated the difficulty to separate physico-chemical processes and physical protection (see below) as factors influencing SOC stabilization. Physico-chemical associations namely tend to promote aggregation. Boudot et al. (1989) observed that the binding of metals (such as $\mathrm{Al}$ and $\mathrm{Fe}$ ) per se in metal-humusclay complexes could not be regarded as responsible for any significant protective effect against biodegradation. The formation of an insoluble metallic hydroxide trapping and wrapping SOC molecules, and therefore either preserving it from access by soluble soil enzymes or preventing their movement to immobile enzymatic constituents associated with microbial cells (=inaccessibility or physical protection), would better account for the observed protective effect than the chemical binding per se.

\section{Physical protection}

Physical protection and aggregation can influence accessibility of substrate to microbes and fauna. Theoretical calculations suggest that aggregation should limit access to SOC (e.g. Van Veen and Kuikman, 1990). Six et al. (2000a) underscored the importance of soil aggregation and more specifically the interactions of SOC and aggregate dynamics in controlling SOC sequestration in soils. Gijsman and Sanz (1998) investigated the physical protection of macroaggregates in Andisols. After crushing of macroaggregates, these authors observed a significant increase in $\mathrm{CO}_{2}$ mineralization compared to intact soil samples. Plante and McGill (2002) indicated that macroaggregate turnover results in the exposure of labile organic matter. Jastrow (1996) found evidence for a relationship between macroaggregate formation and SOC accrual. Aggregate stability affects the $\mathrm{C}$ mineralization process in Andisols by a physically protecting SOC from microbial breakdown. In our soils, the latter was confirmed by the significant correlation between the whole soil $\mathrm{C}$ mineralization rate constants and the difference in WAD $(r=0.39, p=0.04)$.
We believe that this phenomenon is the most important SOC stabilization parameter occurring in our soils. However, it is probably an indirect effect of sorption mechanisms due to the presence of amorphous $\mathrm{Al}$ minerals as described above. Further statistical evidence for this conclusion was found in a significant correlation between the $\mathrm{C}$ mineralization rate constant and $\mathrm{Al}_{\mathrm{ox}}$ content $(r=-0.68, p=0.00)$, and the difference in WAD (Fig. 4). High $\mathrm{Al}_{\mathrm{Ox}}$ contents lead to the formation of stable soil aggregates which offer physical protection to the SOC. The importance of amorphous clay materials for SOC stabilization and aggregation in allophanic Andisols has often been documented (e.g. Boudot et al., 1989; Nanzyo et al.,1993; Torn et al., 1997), and is assumed to be the main stabilization mechanism in this soil type.

\subsection{Effect of soil $\mathrm{pH}$ on SOC stabilization}

Under lower $\mathrm{pH}$ conditions, $\mathrm{Al}$ is more soluble and available for complexation with soil components (Wesselink et al., 1996). The pH differences between GRASS and both SGFOR and PINUS were significant for all soil layers, and most probably a result of the acidifying fertilizer applications. As a result of a lower $\mathrm{pH}$, the extractable $\mathrm{Al}_{\mathrm{ox}}$ and $\mathrm{Al}_{\mathrm{py}}$ concentrations in the GRASS site were higher than for SGFOR and PINUS. We found that allophane contents were significantly lower for GRASS than for SGFOR and PINUS. It was indicated that as a result of a lower $\mathrm{pH}, \mathrm{Al}$ was released from allophanic compounds and consequently resulted in a higher $\mathrm{Al}$ content associated with the Al-humus complexes. Statistical evidence for this conclusion was found by the strong significant correlation between soil $\mathrm{pH}$ and allophane $(r=0.74$, $p=0.00$ ). Increased $\mathrm{Al}$ release from allophane at decreasing $\mathrm{pH}$ was also found by Farmer and Lumsdon (2002). Takahashi et al. (2005) found that as a result of liming treatments, the amounts of organically complexed $\mathrm{Al}$ decreased significantly. Dahlgren and Saigusa (1994) found in Andisols evidence for the precipitation of released $\mathrm{Al}$ from allophanic components on soil surfaces, while Walker et al. (1988) found more specifically that soluble Al was adsorbed extremely rapid on common soil minerals such as vermiculite. Violante and Huang (1992) found in OM rich soils that sorption and aggregation between soil particles was promoted by increasing Al precipitation. Tama and El-Swaify (1978) stated that soil $\mathrm{pH}$ affects the ability of soil particles to aggregate differently in variable charge soils. The electrostatic contribution of oxides to aggregate stability is $\mathrm{pH}$ dependent and affects the extent of aggregate breakdown at different $\mathrm{pH}$ values. In lowering soil $\mathrm{pH}$, the amount of positive charges of the Al-oxides and allophane increases (Espinoza et al., 1975). As such, more electrostatic forces are involved in aggregating soil particles. However, in our statistical analyses of the aggregate stability test no significant correlation was found between soil $\mathrm{pH}$ and difference in WAD between the two fractionation procedures. Possibly, 
the sigmoid retention curves, relating the effect of soil $\mathrm{pH}$ and positive charges, documented in south Chilean Andisols (Espinoza et al., 1975) might be responsible for the absence of a linear correlation.

\section{Conclusions}

It can be concluded that by electrostatic sorption between and among amorphous Al compounds and clay minerals, physico-chemical stabilization of the SOC occurs. As clay minerals are closely associated with organic matter compounds, stable metal-humus-clay complexes can be formed. The principle of aggregate hierarchy was not valid in this soil type as metal-humus complexes formed as a result of ligand exchange did not appear to be important binding agents between soil aggregates. Soil $\mathrm{pH}$ is an important parameter in the studied Andisol as it influences aggregate stability. It was shown that SOC stabilization occurred via the formation of metal-humus-clay complexes and physical protection of SOC in soil aggregates. The recalcitrance of the SOC did not appear to influence SOC stabilization.

The whole soil $\mathrm{C}$ mineralization constants of the different land use treatments decreased in the following order: $\mathrm{SGFOR} \approx \mathrm{PINUS}>$ GRASS. In this study, land use conversion from a second growth forest (SGFOR) to a grassland (GRASS) showed, indirectly, a positive effect on C stabilization in the soil. As a result of management practices soil pH decreased in GRASS and more metal-humus-clay complexes and stable soil aggregates could be formed. A higher physical protection of the SOC was reached on this site, resulting in lower $\mathrm{C}$ mineralization rates. Other influences due to management practices (ploughing and direct exposition to sunlight due to the absence of a vegetation cover), and differences in root $C$ input might influence as well SOC stabilization in the different sites.

Acknowledgements. This research was supported by the Fund for Scientific Research - Flanders (Belgium) (FWO), the Fondecyt Project No. 1020989 Millenium Nucleus Forecos P01-057-F, and the Bilateral Scientific and Technological Cooperation between Flanders and Chile. We thank the Flemish Interuniversity Council (VLIR) for the assignment of a scholarship for the research work in Chile.

Edited by: E.-D. Schulze

\section{References}

Accoe, F., Boeckx, P., Van Cleemput, O., Hofman, G., Hui, X., Bin, H., and Guanxiong, C.: Characterization of soil organic matter fractions from grassland and cultivated soils via $\mathrm{C}$ content and $\delta^{13} \mathrm{C}$ signature, Rapid Commun. Mass Spectrom., 16, 2157-2164, 2002.

Baldock, J. A. and Skjemstad, J. O.: Role of the soil matrix and minerals in protecting natural organic materials against biological attack, Org. Geochem., 31, 697-710, 2000.
Beare, M. H., Hendrix, P. F., and Coleman, D. C.: Water-stable aggregates and organic matter fractions in conventional and notillage soils, Soil Sci. Soc. Am. J., 58, 777-786, 1994.

Bertsch, P. M. and Bloom, P. R.: Aluminum, in: Methods of soil analysis Part 3- Chemical methods, edited by: Sparks, D. L., SSSA Book Series, SSSA, Madison, 1996.

Besoain, E. M.: Clay mineralogy of volcanic ash soils, Panel of Volcanic ash soils in Latin America, Soil B.1.1-B.1.16., Turrialba, Costa Rica, 1969.

Besoain, E. M.: Mineralogia de las arcillas de algunos suelos volcánicos de Chile, Agr. Téc., 18, 110-165, 1958.

Besoain, E. M., Peralta, M. P., and Massaro, S. M.: Mineralogía y genesis de algunas suelos de cenizas volcánicas de Chiloé continental, Chile, Agr. Téc., 60, 127-153, 2000.

Birkland, P.: Soils and geomorphology, Oxford University Press, New York, 1984.

Boudot, J.-P., Bel Hgadj, B. A., and Chone, T.: Carbon mineralization in Andosols and aluminium-rich highland soils, Soil Biol. Biochem., 18, 457-461, 1986.

Boudot, J.-P., Bel Hadj, B. A., Steiman, R., and Seigle-Murandi, F.: Biodegradation of synthtic organo-metallic complexes of iron and aluminium with selected metal to carbon ratios, Soil Biol. Biochem., 21, 961-966, 1989.

Brown, S. and Lugo, E. A.: Effects of forest clearing and succession on the carbon and nitrogen content of soils in Puerto Rico and US Virgin Islands, Plant Soil, 124, 53-64, 1990.

Burchill, S., Greenland, D. J., and Hayes, M. H. B.: Adsorption of organic molecules, in: The chemistry of soil processes, edited by: Greenland, D. J. and Hayes, M. H. B., Wiley, Chichester, 221-400, 1981.

Dahlgren, R. A. and Saigusa, M.: Aluminum release rates from allophanic and nonallophanic andosols, Soil Sci. Plant Nutr., 40, 125-136, 1994.

de Koning, G. H. J., Veldkamp, E., and López-Ulloa, M.: Quantification of carbon sequestration in soils following pasture to forest conversion in northwestern Ecuador, Global Biogeochem. Cycles, 17 (4), Art. No. 9, doi:101029/2003GB002099, 2003.

De Leenheer, L. and De Boodt, M.: Determination of aggregate stability by the change in Mean Weight Diameter, Proceedings of the international symposium on soil structure, Gent, Belgium, Rijkslandbouwhogeschool, Gent, Belgium, 290-300, 1959.

Del Galdo, I., Six, J., Peressotti, A., and Cotrufo, M. F.: Assessing the impact of land-use change on soil $\mathrm{C}$ sequestration in agricultural soils by means of organic matter fractionation and stable $\mathrm{C}$ isotopes, Global Change Biol., 9, 1204-1213, 2003.

Denef, K., Six, J., Merckx, R., and Paustian, K.: Short-term effects of biological and physical forces on aggregate formation in soils with different clay mineralogy, Plant Soil, 246, 185-200, 2002.

Elliott, E. T.: Aggregate structure and carbon, nitrogen and phosphorus in native and cultivated soils, Soil Sci. Soc. Am. J., 50, 627-633, 1986.

El-Swaify, S. A.: Physical and mechanical properties of Oxisols, in: Soils with variable charge, edited by: Theng, B.K.G., Offset Publ., Palmerston North, 303-324, 1980.

Espinoza, W., Gast, R. G., and Adams, R. S. J.: Charge characteristics and nitrate retention by two Andepts from south-central Chile, Soil Sci. Soc. Am. J., 39, 842-846, 1975. 
FAO-UNESCO: Soil map of the world, Volume IV, South America, UNESCO, Paris, 1971.

Farmer, V. C. and Lumsdon, D. G.: A re-interpretation of 'Aluminium solubility mechanisms in moderately acid Bs horizons of podzolized soils' by Gufstafsson et al., Eur. J. Soil Sci., 53, 671-673, 2002.

Galindo, G. G., and Bingham, T.: Homovalent and heterovalent cation exchange equilibria in soils with variable surface charge, Soil Sci. Soc. Am. J., 41, 833-866, 1977.

Gijsman, A. J. and Sanz, J. I.: Soil organic matter pools in a volcanic-ash soil under fallow or cultivation with applied chicken manure, Eur. J. Soil Sci., 49, 427-436, 1998.

Guo, L. B. and Gifford, R. M.: Soil carbon stocks and land use change: a meta analysis, Global Change Biol., 8, 345-360, 2002.

Hassink, J.: Density fractions of soil macroorganic matter and microbial biomass as predictors of $\mathrm{C}$ and $\mathrm{N}$ mineralization, Soil Biol. Biochem., 27, 1099-1108, 1995.

Hoyos, N. and Comerford, N. B.: Land use and landscape effects on aggregate stability and total carbon of Andisols from the Colombian Andes, Geoderma, accepted, 2005.

Jastrow, J. D.: Soil aggregate formation and the accrual of particulate and mineral-associated organic matter, Soil Biol. Biochem., 28, 665-676, 1996.

Jobbagy, E. G. and Jackson, R. B.: The vertical distribution of soil organic carbon and its relation to climate and vegetation, Ecol. Appl., 10, 423-436, 2000.

Juste, C., Delas, J., and Langon, M.: Comparison de la stabilit biologique de différents humates métalliques, C. R. Acad. Sci., 281, 1685-1688, 1975.

Kaiser, K. and Zech, W.: Defects in estimation of aluminum in humus complexes of podzolic soils by pyrophosphate extraction, Soil Sci., 161, 452-458, 1996.

Klute, A.: Methods of Soil Analysis (2nd Ed.), Agronomy Monograph Vol. 9, ASA-SSSA, Madison, 1986.

Kubota, T.: Aggregate formation of allophonic soils: effect of drying on the dispersion of the soils, Soil Sci. Plant Nutr., 18, 79-87, 1972

Lal, R., Kimble, J. M., Levine, E., and Stewart, B. A.: World soils and greenhouse effect: an overview, in: Soils and global change, edited by: Lal, R., Kimble, J. M., Levine, E., and Stewart, B. A., CRC Lewis Publishers, Boca Raton, 1-7, 1995.

Lara, A., Solari, M. E., Rutherford, P., Thiers, O., Tracaman, R., Molina, R., Prieto, R., and Montory, C.: Cobertura de la vegetación original de la Ecoregión de los bosques valdivianos en Chile hacia 1550, Informe Técnico, Proyecto FB 49WWF/Universidad Austral de Chile, Valdivia, Chile, 1999.

Marschner, B. and Kalbitz, K.: Controls of bioavailability and biodegradability of dissolved organic matter in soil, Geoderma, 113, 211-235, 2003.

Martin, J. P., Zunino, H., Peirano, P., Caiozzi, M., and Haider, K.: Decomposition of 14C-labilled lignins, model humic acid polymers and fungal melanins in allophanic soils, Soil Biol. Biochem., 14, 289-293, 1982.

Meijboom, F. W., Hassink, J., and Van Noordwijk, M.: Density fractionation of soil macroorganic matter using silica suspensions, Soil Biol. Biochem., 27, 1109-1111, 1995.

Milford, M. H.: Soils and Soils Science: Laboratory excercises, 4th Ed., Texas A\&M University, Kendall/Hunt Publishing Company, Dubuqua, Iowa, 1997.
Mizota, C. and van Reeuwijk, L. P.: Clay mineralogy and chemistry of soils formed in volcanic material in diverse climatic regions, Soil Monogr. 2, Int. Soil Reference and Information Centre, Wageningen, The Netherlands, 1989.

Nanzyo, M., Dahlgren, R. A., and Shoji, S.: Chemical characteristics of volcanic ash soils, in: Volcanic ash soils: Genesis, properties and utilization, edited by: Shoji, S., Nanzyo, M. and Dahlgren, R. A., Developments in Soil Science 21, Elsevier, Amsterdam, the Netherlands, 145-187, 1993.

Oades, J. M. and Waters, A. G.: Aggregate hierarchy in soils, Aust. J. Soil Res., 29, 815-828, 1991.

O'Brien, B. J. and Stout, J. D.: Movement and turnover of soil organic matter as indicated by carbon isotope measurements, Soil Biol. Biochem., 10, 309-317, 1978.

Parfitt, R. L.: Allphane in New Zealand - a review, Aust. J. Soil Res., 28, 343-360, 1990.

Parfitt, R. L., Fraser, A. R., and Farmer, V. C.: Adsorption on hydrous oxides. III. Fulvic acid and humic acid on goethite, gibbsite and imogolite, J. Soil Sci., 28, 289-296, 1977.

Parfitt, R. L. and Wilson, A. D.: Estimation of allophane and halloysite in three sequences of volcanic soils, New Zealand, in: Volcanic soil, edited by: Caldas, E. F. and Yaalon, D. H., CATENA suppl. 7, Catena, Braunschweig, Germany, 1-8, 1985.

Parfitt, R. L., Yuan, G., and Theng, B. K. G.: A 13C-NMR study of the interactions of soil organic matter with aluminium and allophane in podzols, Eur. J. Soil Sci., 50, 695-700, 1999.

Paul, K. I., Polglase, P. J., Nyakuengama, J. G., and Khanna, P. $\mathrm{K}$.: Change in soil carbon following afforestation, Forest Ecol. Manag., 168, 241-257, 2002.

Percival, H. J., Parfitt, R. L., and Scott, N.: Factors controlling soil carbon levels in New Zealand grasslands: Is clay content important?, Soil Sci. Soc. Am. J., 64, 1623-1630, 2000.

Plante, A. F. and McGill, W. B.: Intraseasonal soil macroaggregate dynamics in two contrasting field soils using labeled tracer spheres, Soil Sci. Soc. Am. J., 66, 1285-1295, 2002.

Puget, P., Chenu, C., and Balasdent, J.: Total and young organic matter distributions in aggregates of silty cultivated soils, Eur. J. Soil Sci., 46, 449-459, 1995.

Radcliffe, D. J. and Gillman, G. P.: Surface charge characteristics of volcanic ash soils from the southern highlands of Papua New Guinea, in: Volcanic soil, edited by: Caldas, E. F. and Yaalon, D. H., CATENA suppl. 7., Catena, Braunschweig, Germany, 35-46, 1985.

Schofield, R. K. and Samson, H. R.: Flocculation of kaolinite due to the attraction of oppositely charged crystal faces, Faraday Dis., $18,135-145,1954$

Schwertmann, U.: Differenzierung der Eisenoxide des Bodens durch photochemische Extraction mit saurer ammoniumoxalate Lösung, Z. Pflanzenernaehr. Bodenkd., 105, 194-202, 1964.

Shoji, S., Nanzyo, M., and Dahlgren, R. A.: Volcanic ash soilsGenesis, properties and utilization, Developments in Soil Science, 21, Elsevier, Amsterdam, 1993.

Six, J., Elliott, E. T., and Paustian, K.: Aggregate and soil organic matter dynamics under conventional no-tillage systems, Soil Sci. Soc. Am. J., 63, 1350-1358, 1999.

Six, J., Elliott, E. T., and Paustian, K.: Soil macroaggregate turnover and microaggregate formation: a mechanism for $\mathrm{C}$ sequestration under no-tillage agriculture, Soil Biol. Biochem., 32, 2099-2103, 2000a. 
Six, J., Elliott, E. T., and Paustian, K.: Soil structure and soil organic matter: II. A normalized stability index and the effect of mineralogy, Soil Sci. Soc. Am. J., 64, 1042-1049, 2000 b.

Six, J., Paustian, K., Elliott, E. T., and Combrink, C.: Soil structure and soil organic matter: I. Distribution of aggregate size classes and aggregate associated carbon, Soil Sci. Soc. Am. J., 64, 681689, 2000c.

Skjemstad, J. O.: Genesis of Podzols on coastal dunes in southern Queensland: III. The role of aluminium-organic complexes in profile development, Aust. J. Soil Res., 30, 645-665, 1992.

Sollins, P., Homann, P., and Caldwell, B. A.: Stabilization and destabilization of soil organic matter: mechanisms and controls, Geoderma, 74, 65-105, 1996.

Solomon, D., Lehmann, J., and Zech, W.: Land use effects on soil organic matter properties of chromic Luvisols in semi-arid northern Tanzania: carbon, nitrogen, lignin and carbohydrates, Agr. Ecosyst. Environ., 78, 203-213, 2000.

Swanston, C. W., Caldwell, B. A., Homann, P. S., Ganio, L., and Sollins, P.: Carbon dynamics during a long-term incubation of separate and recombined density fractions from seven forest soils, Soil Biol. Biochem., 34, 1121-1130, 2002.

Takahashi, T., Ikeda, Y., Fujita, K., and Nanzyo, M.: Effect of liming on organically complexed aluminum of nonallophanic Andosols from northeastern Japan, Geoderma, accepted , 2005.

Tama, K. and El-Swaify, S. A.: Charge, colloidal, and structural stability relationships in oxidic soils, in: Modification of soil structure, edited by: Emerson, W. W., Bond, R. D., and Dexter, A. R., John Wiley \& Sons, Chicester, 41-52, 1978.

Tisdall, J. M. and Oades, J. M.: Organic matter and water-stable aggregates in soils, J. Soil Sci., 33, 141-163, 1982.

Torn, M. S., Trumbore, S. E., Chadwick, O. A., Vitousek, P. M., and Hendricks, D. M.: Mineral control of soil organic storage and turnover, Nature, 389, 170-170, 1997.
Tosso, J.: Suelos volcánicos de Chile, Instituto de Investigaciones Agropecuarias, Santiago, Chile, 1985.

Van Veen, J. A. and Kuikman, P. J.: Soil structural aspects of decomposition of organic matter by microorganisms, Biogeochemistry, 11, 213-233, 1990.

Varadachari, C., Mondal, A. H., and Ghosh, K.: The influence of crystal edges on clay-humus complexation, Soil Sci., 159, 185190, 1995.

Violante, A. and Huang, P. M.: Effect of tartaric acid and $\mathrm{pH}$ on the nature and physicochemical properties of short-range ordered aluminum precipitation products, Clays Clay Miner., 40, 462469, 1992.

Walker, W. J., Cronan, C. S., and Patterson, H. H.: A kineticstudy of aluminum adsorption by aluminosilicate clay-minerals, Geochim. Cosmochim. Acta, 52, 55-62, 1988.

Wesselink, L. G., van Breemen, N., Mulder, J., and Janssen, P. H.: A simple model of soil organic matter complexation to predict the solubility of aluminium in acid forest soils, Eur. J. Soil Sci., 47, 373-384, 1996.

Wilde, S. A.: Changes in soil productivity induced by pine plantations, Soil Sci., 97, 276-278, 1964.

Yakimenko, E. Y.: Soil comparative evolution under grasslands and woodlands in the forest zone of Russia, in: Management of carbon sequestration in soil, edited by: Lal, R., Kimble, J. M., Follet, R. F., and Stewart, B. A., CRC Press, Boca Raton, 391-404, 1998.

Zunino, H., Borie, F., Aguilera, S., Martin, J. P., and Haider, K.: Decomposition of $14 \mathrm{C}$ labeled glucose, plant and microbial products and phenols in volcanic ash-derived soils of Chile, Soil Biol. Biochem., 14, 37-43, 1982. 